\title{
Oceanic Impact on European Climate Changes during the Quaternary
}

\author{
Gloria M. Martin-Garcia
}

Department of Natural Sciences, Instituto E. S. Francisco Salinas, C/ Julita Ramos s/n, 37004 Salamanca, Spain; gm.martin@usal.es; Tel.: +34-686-042-731

Received: 28 January 2019; Accepted: 5 March 2019; Published: 8 March 2019

\begin{abstract}
Integrative studies on paleoclimate variations over oceanic and continental regions are scarce. Though it is known that Earth's climate is strongly affected by sea-air exchanges of heat and moisture, the role of oceans in climate variations over land remains relatively unexplored. With the aim to unveil this influence, the present work studies major climate oscillations in the North Atlantic region and Europe during the Quaternary, focusing on the oceanic mechanisms that were related to them. During this period, the European climate experienced long-term and wide-amplitude glacial-interglacial oscillations. A covariance between the North Atlantic sea surface temperature and climate signals over the continent is especially observed in Southern Europe. The most severe and drastic climate changes occurred in association to deglaciations, as a consequence of major oceanographic reorganizations that affected atmospheric circulation and ocean-atmosphere heat-flow, which led to variation of temperature and precipitation inland. Most deglaciations began when Northern Hemisphere summer insolation was maximal. Increased heating facilitated the rapid ice-sheet collapse and the massive release of fresh water into the Northern Atlantic, which triggered the weakening or even the shutdown of the North Atlantic Deep Water (NADW) formation. Though the extension of ice-sheets determined the high-latitude European climate, the climate was more influenced by rapid variations of ice volume, deep-water formation rate, and oceanic and atmospheric circulation in middle and subtropical latitudes. In consequence, the coldest stadials in the mid-latitude North Atlantic and Europe since the early Pleistocene coincided with Terminations (glacial/interglacial transitions) and lesser ice-sheet depletions. They were related with decreases in the NADW formation rate that occurred at these times and the subsequent advection of subpolar waters along the western European margin. In Southern Europe, steppe communities substituted temperate forests. Once the freshwater perturbation stopped and the overturning circulation resumed, very rapid and wide-amplitude warming episodes occurred (interstadials). On the continent, raised temperature and precipitations allowed the rapid expansion of moisture-requiring vegetation.
\end{abstract}

Keywords: Quaternary climate; ocean-land interactions; north Atlantic; European climate

\section{Introduction}

\subsection{Quaternary and Climate}

The Quaternary period is characterized by the existence of extensive ice sheets that covered part of the continental surface and their periodic advance/retreat oscillations, which conditioned global climate at orbital time-scales [1-4] (Figure 1). Each climate cycle began with a very warm interval, known as the interglacial optimum, and usually coincided with minimum ice volume (Figure 2). Models suggest that during some climate optima, like during the interglacial Marine Isotope Stage (MIS) 11 or the MIS 5 interglacial optimum, the extension of ice sheets was even smaller than it is today [5]. A progressive cooling and growth of ice sheets followed the interglacial optimum. 
The cooling did not occur continuously but through rapid cool-warm oscillations of a lesser amplitude than the glacial-interglacial one. This deterioration of climate culminated with the greatest ice volume within the cycle, known as glacial maximum. Climatic cycles finished with a rapid deglaciation, known as the Termination (T), that connected with the following interglacial optimum (Figure 2).

The amplitude and duration of climate cycles were modulated by variations of the Earth's orbital parameters, the combination of which results in the orbital cycles described by Milankovitch [6]. During the early Pleistocene, climate cycles were symmetrical, of low amplitude, and tuned to obliquity (periods of $41 \mathrm{ky}$ ). In the last million years, climate phasing gradually changed into asymmetrical, wide amplitude, and eccentricity-tuned cycles (100 ky periodicity). This transition is known as the Mid-Pleistocene Transition (MPT) and, although there is not a total agreement about its timing and duration, it is clear that strong $100 \mathrm{ky}$ cycles have happened since $600 \mathrm{ka}$ [7-9] (Figure 1).

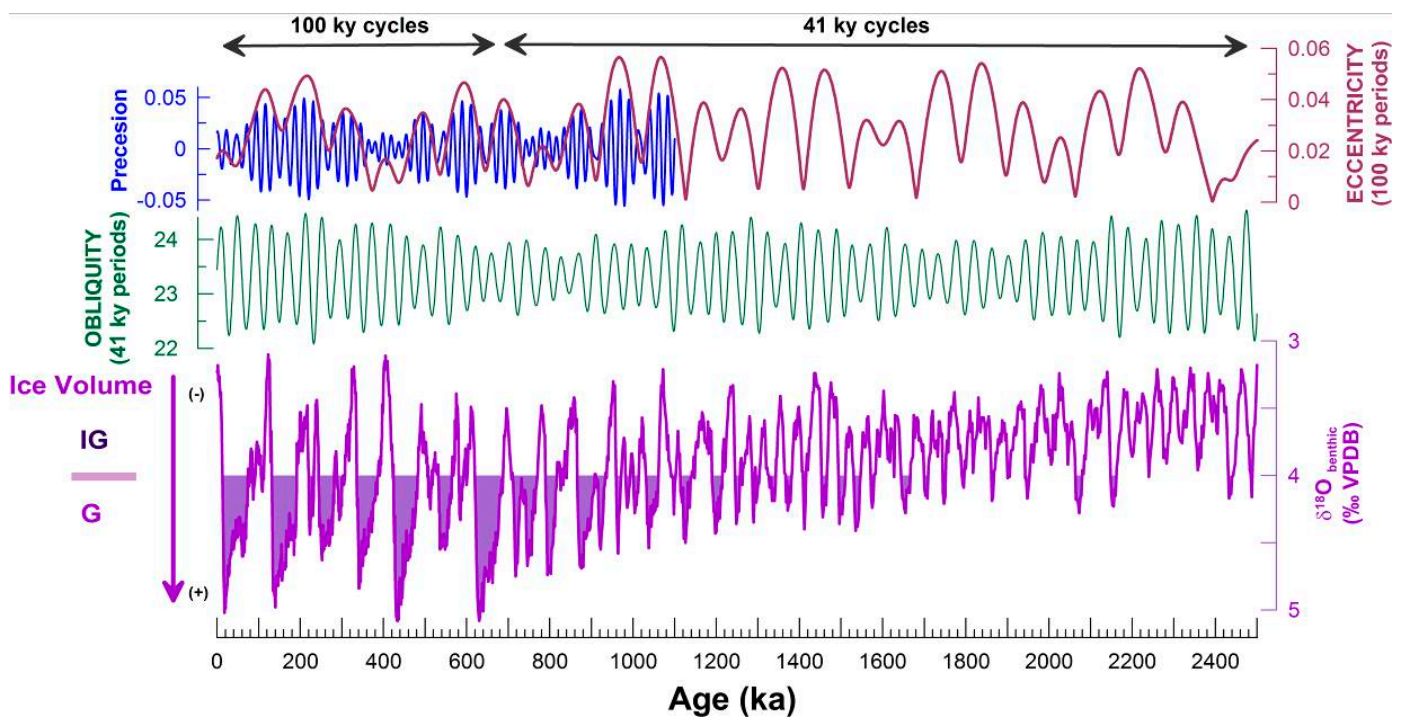

Figure 1. Climate cycles during the Quaternary and their correspondence with orbital parameters. From bottom to top: The ice volume is indicated by the benthic $\delta^{18} \mathrm{O}$ [10]; purple fill shows the ice volume threshold separating glacial $(\mathrm{G})$ and interglacial (IG) conditions. Orbital parameters are from [11].

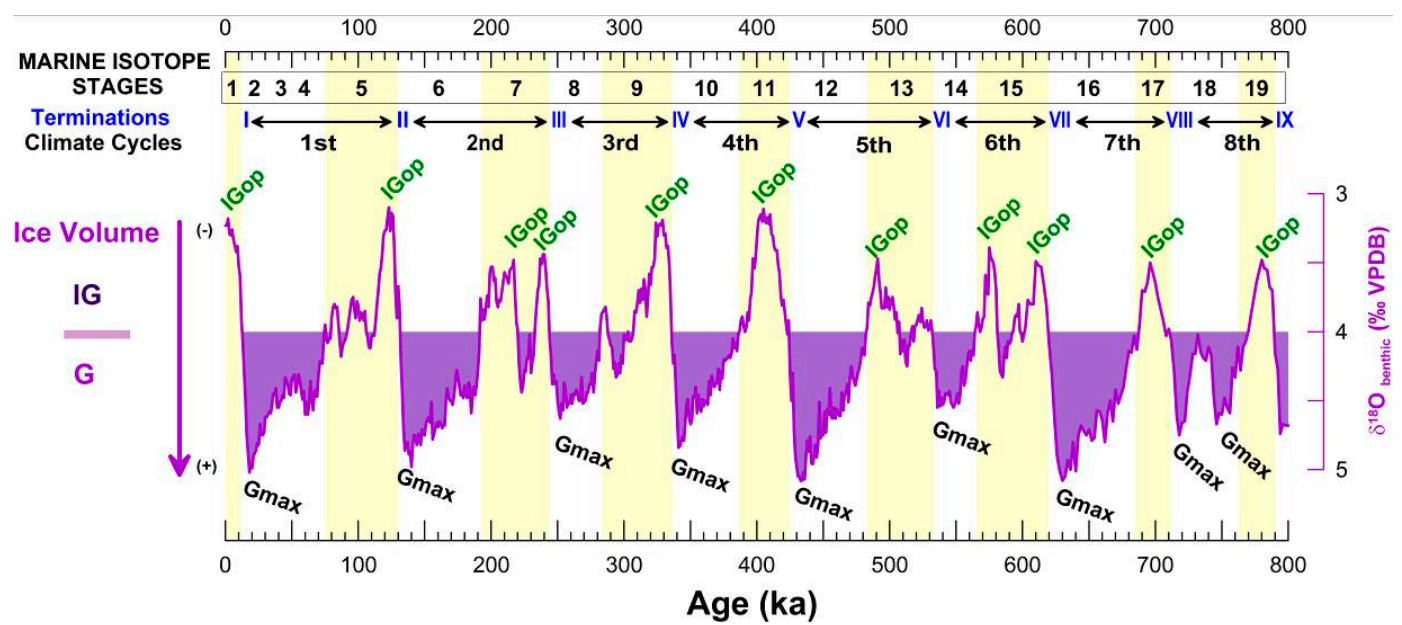

Figure 2. Glacial cycles for the last 800,000 years. The ice volume is indicated by the benthic $\delta^{18} \mathrm{O}[10]$; purple fill shows the ice volume threshold separating glacial $(G)$ and interglacial (IG) conditions. Marine isotope stages, terminations (in roman numerals), and climate cycles are represented on top. Yellow bands highlight interglacial stages, which are defined by convention. Iop, interglacial optimum; Gmax, glacial maximum. 
At a suborbital time scale, the existing discrepancies between climatic records and orbital parameters suggest that other factors also contributed to modulate the climate system. Some of these factors are atmospheric concentration of greenhouse gases $\mathrm{CH}_{4}$ and $\mathrm{CO}_{2}$ [8,12-15], oceanic circulation [16-19], ice sheets size, and the albedo effect [20,21]. In the North Atlantic, for instance, millennial-scale iceberg surges deeply altered the ocean's heat conveyor and caused fundamental reorganisations of the ocean-climate system. This resulted in extreme cooling episodes, known as Heinrich events, that affected the whole region repeatedly during the middle and late Pleistocene [22-26]. Heinrich events had a duration from a few hundred to a thousand years and a recurrence of $\sim 7-10 \mathrm{ky}[27,28]$. Temperature in the polar region, in turn, underwent a series of decadal-frequency and wide-amplitude stadial-interstadial (cold-warm) shifts that could reach up to $15^{\circ} \mathrm{C}$ oscillation $[29,30]$. These so-called Dansgaard-Oeschger (D-O) oscillations were registered in the Greenland ice and grouped in sequences of progressively cooler events [31,32]. Such sequences are known as Bond cycles [33] and are linked to changes in the mode of overturning circulation in the North Atlantic [34]. Most Heinrich events happened at the end of a Bond cycle, coinciding with its coldest stadial, and were followed by warming to almost interglacial temperatures [35,36] (Figure 3).

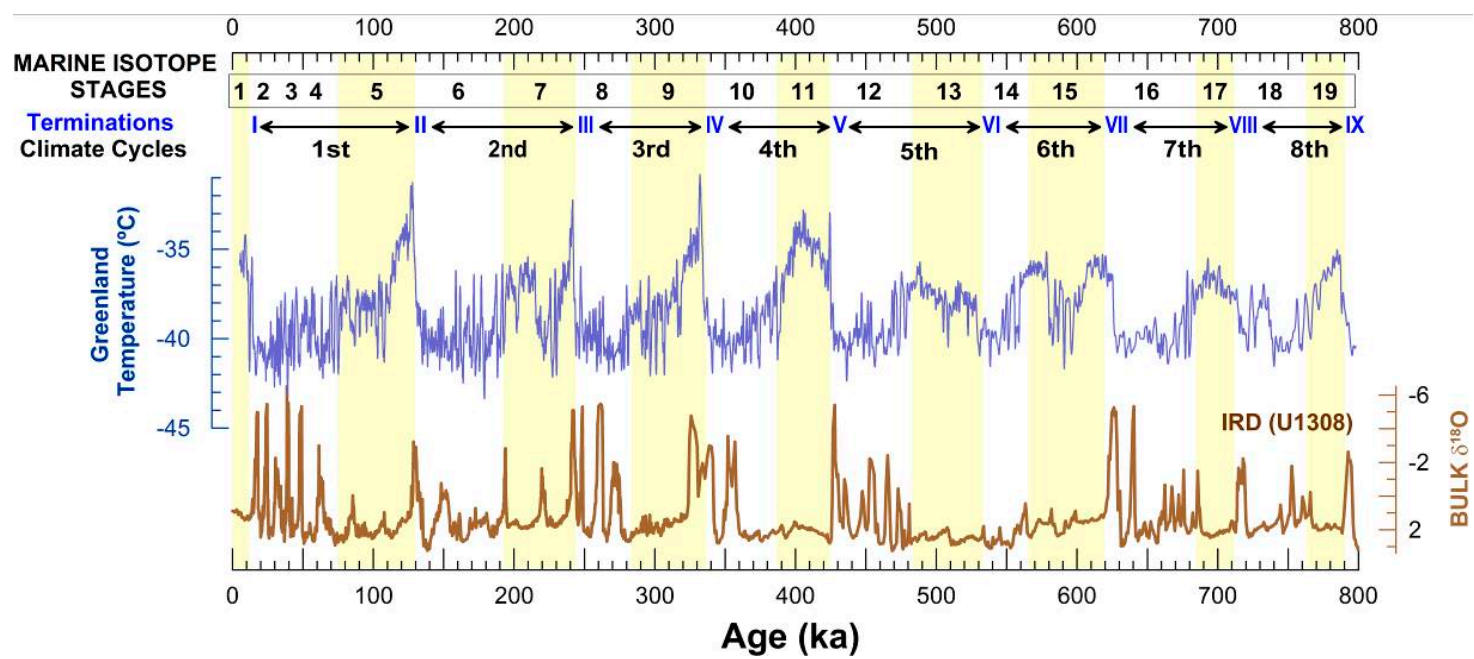

Figure 3. Temperature reconstruction for Greenland [37], compared with the occurrence of Heinrich Events, as indicated by the Ice Rafted Debris (IRD) record from the North Atlantic site U1308 $\left(49^{\circ} 52.67^{\prime} \mathrm{N}, 24^{\circ} 14.3^{\prime} \mathrm{W}\right)$ [25]. Marine isotope stages, Terminations (in roman numerals), and climate cycles are represented on top. Yellow bands highlight interglacial stages.

\subsection{Climate Regime in the North Atlantic Region}

According to studies on the Holocene climate, ocean dynamics (especially heat transport) control Sea surface temperature (SST) and influence climate variations on decadal timescales. Interannual variations, on the other hand, are mainly driven by atmospheric heat flux changes [38]. Due to the large heat capacity of water when compared to the atmosphere, changes in SST can alter the global circulation of the atmosphere, releasing - with certain delay-the heat accumulated in the upper ocean as latent and sensible heat fluxes; thus, changes in SST can trigger, in this way, teleconnections. The most important teleconnection pattern affecting Western Europe is the North Atlantic Oscillation (NAO), which is associated with changes in the meridional gradient between the subpolar and subtropical pressure systems. As with other teleconnection patterns, NAO has a significant impact on other atmospheric surface variables such as temperature and precipitation, so it can be used as a useful intermediate index to relate changes in the North Atlantic Ocean state (e.g., SST or circulation) and European Climate. 
The climate regime over mid-latitude North Atlantic and Western Europe is mainly governed by the position and intensity of the Azores high-pressure area $(\mathrm{AzH})$ and its variation through the annual seasonal cycle. During spring/summer, the AzH migrates northward and induces strong northerly winds, while, during fall/winter months, the AzH and its associated wind-system are significantly weaker $[39,40]$. In consequence, this region is under the influence of the North Atlantic Oscillation (NAO) anomaly. This anomaly is measured by the NAO index, which records the difference in atmospheric pressure between the Iceland low and the $\mathrm{AzH}$. The anomaly is positive $\left(\mathrm{NAO}^{+}\right)$when the $\mathrm{AzH}$ is reinforced, and the difference with the Iceland low is greater. In this scenario, westerly winds become stronger and the Gulf Stream migrates northward, which results in anomalously mild and wet winters for Northern Europe, while Southern Europe becomes anomalously cold and dry [41]. In Southwest Europe, $\mathrm{NAO}^{+}$phases are associated with the reinforcement of the seasonal upwelling off Portugal, via the strengthening of northeast trade winds. In $\mathrm{NAO}^{-}$conditions, the westerlies are weaker, the Gulf Stream is located southward, climate in Northwest Europe is dry while in South Europe is wet, and off Iberia the Azores Current prevails, inducing warm conditions and the reduction of the upwelling [42]. The NAO also affects the sea ice coverage in the North Atlantic [43] and, indirectly, the thermohaline circulation [42].

Other teleconnection patterns that affect the North Atlantic region include the position of the Inter Tropical Convergence Zone (ITCZ) and the "El Niño/Southern Oscillation" (ENSO). Periods of southward migration of the ITCZ are related with cooling in the North Atlantic. During these periods, less evaporation over the Caribbean resulted in decreased salinity of surface water. The Gulf Stream transported this water to a subpolar latitude, where its relatively low salinity hampered the surface-water sinking-rate. This weakened the Atlantic meridional overturning circulation (AMOC) and favored the expansion of cold, subpolar water over the North Atlantic [44-47]. ENSO, on its turn, influences Southern Europe's climate, specifically the Iberian Peninsula's. For instance, rainfall in Iberia is controlled by both ENSO and NAO phenomena [48,49]. The western part of the peninsula is generally more under the influence of NAO in winter, while the eastern part is under the influence of ENSO in spring and autumn.

\section{Causes of Major Climate Changes in the European Atlantic Margin Associated with Deglaciations}

\subsection{North Atlantic Circulation and SST Oscillations}

The western European margin is under the influence of the North Atlantic eastern gyre that consists of two branches, the North Atlantic Current (NAC) in the North and the Azores Current (AzC) in the South (Figure 4). The NAC conforms a wide transition zone between the cold polar waters and the warm subtropical waters of the $\mathrm{AzC}$; the Artic Front (AF) and the Azores Front separate the three masses of water. When the NAC reaches the continental margin, it diverts southwards and advects water of subpolar origin $\left(\sim 46^{\circ}\right)$ along mid-latitude and Southern Europe- the Portugal Current [50,51]. The AzC, in turn, forms along the Azores Front at about 35-37 $\mathrm{N}$ [52] and flows eastwards. While approaching the continent, it bifurcates into two branches, the northern one being the lberian Poleward Current (IPC) [53]. This one advects warm waters northwards, overflowing the PC until $\sim 42^{\circ} \mathrm{N}$ [54]. This surface limit between masses of water of subpolar and subtropical origin can vary depending on their thermohaline characteristics and on the migration of the AzH. Changes in the intensity of the northward flow in the North Atlantic drive a deep impact on the subpolar and subtropical gyres as well as on the position of the Arctic and subtropical fronts. Such changes, in turn, influence the strength of the currents and the origin of the water masses that bathe the Atlantic European margin at different latitudes.

During Terminations and other important reductions of ice volume, profound reorganizations of the North Atlantic circulation occurred that reduced the northward flow of warm water. This sharp decrease of the heat flow resulted in the most rapid and coldest events registered in the mid-latitude North Atlantic during the Quaternary, including the most severe glacial maxima [56-59]. Such cooling affected the whole European margin. For instance, during some of these events, the Southwestern 
Iberian margin registered drops of $8{ }^{\circ} \mathrm{C}$ in the winter SST that reached $\sim 6.2{ }^{\circ} \mathrm{C}[56,60]$-today's temperature being $15.5^{\circ} \mathrm{C}$ [61] (Figure 5). The amplitude and duration of these cooling episodes were directly related with the magnitude of the ice volume reduction. Sudden and wide-amplitude warming-up to $11^{\circ} \mathrm{C}$ oscillation-followed the cooling and marked the climate optimum of the succeeding interglacial $[60,62]$.

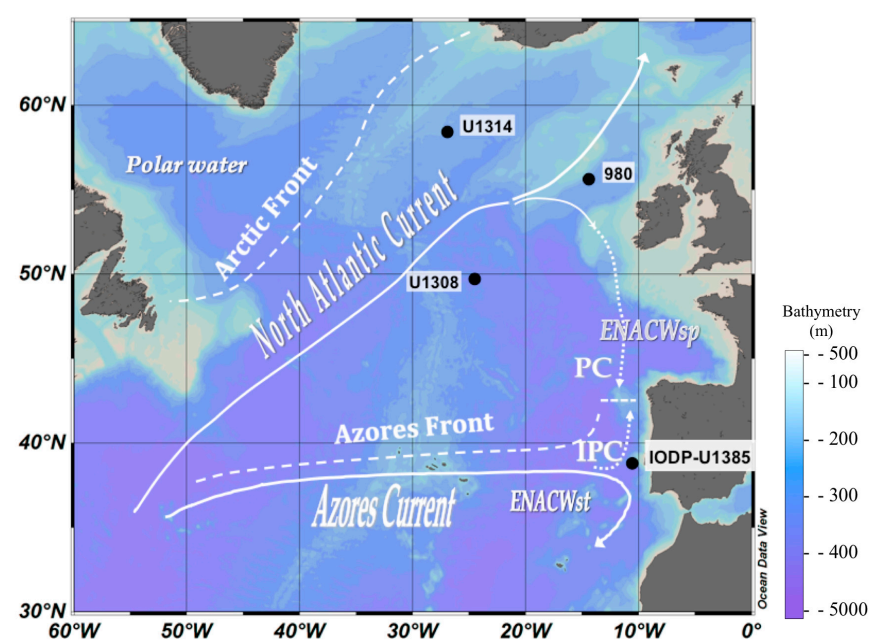

Figure 4. Map showing the North Atlantic surface currents that bathe mid-latitude European margin and the location of sites mentioned in the text. ENACWsp: Eastern North Atlantic Central Water of subpolar origin; ENACWst: Eastern North Atlantic Central Water of subtropical origin; IPC: Iberian Poleward Current; PC: Portugal Current. The position of the Arctic Front is taken from [55].

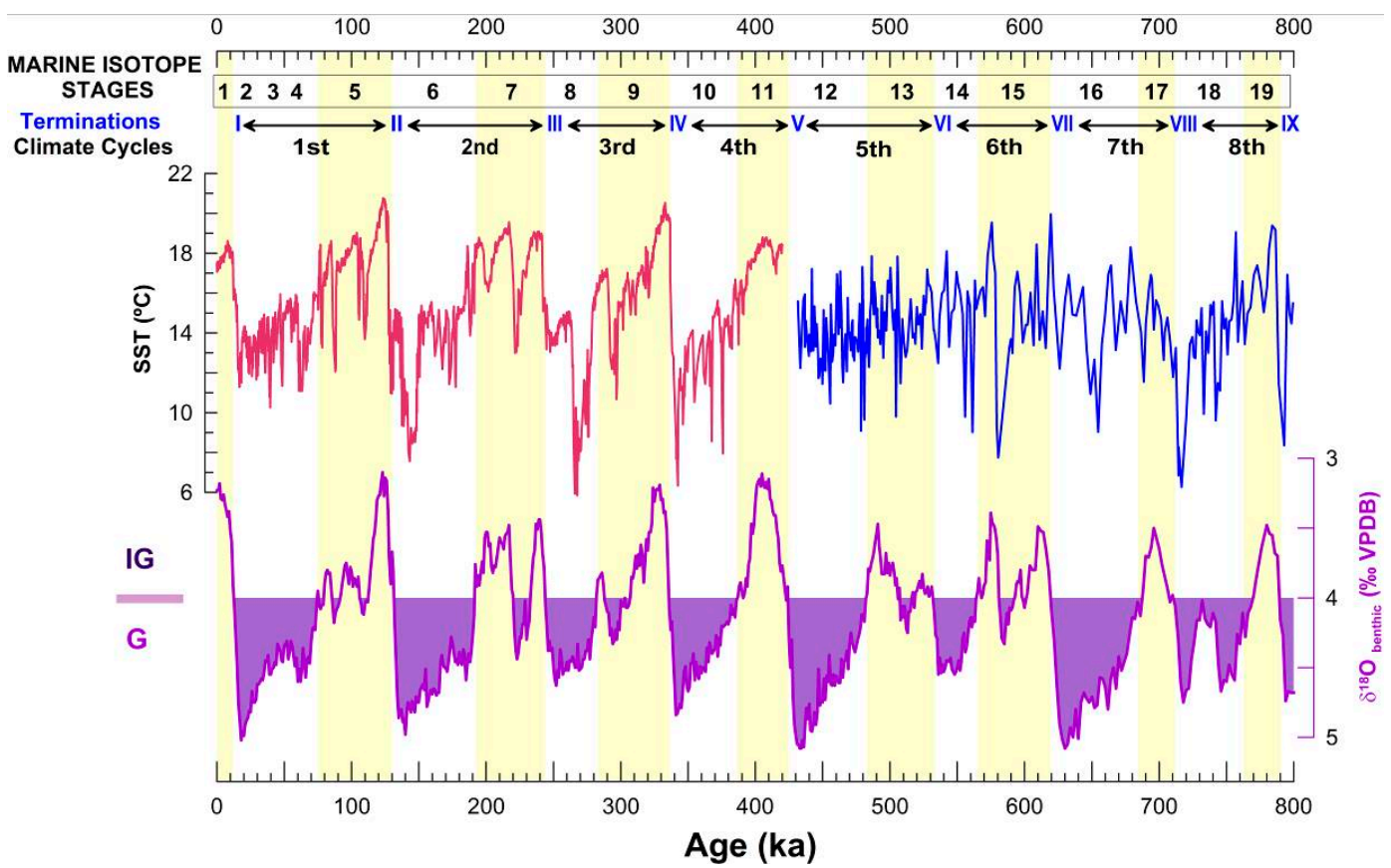

Figure 5. Sea surface temperature (SST) oscillation in the Southwest Iberian margin compared with global ice volume. The ice volume is indicated by $\delta^{18} \mathrm{O}$ [10]; purple fill shows the ice volume threshold separating glacial (G) and interglacial (IG) stages. Alkenone-based SST (in red) records the temperature of the upper $\sim 10 \mathrm{~m}$ [56]. Foraminifer-based SST [62], on the other hand, registers the average temperature of the upper $\sim 100 \mathrm{~m}$ [63]. The apparent discrepancy between both signals suggests that the uppermost ocean is more affected by climate variations than the subsurface water. Marine isotope stages, terminations (in roman numerals), and climate cycles are represented on top. Yellow bands highlight interglacial stages. 
Climate in the western European margin, especially in middle latitudes, is influenced by surface and deep North Atlantic circulation. Therefore, to better understand why main climate changes here occurred during deglaciations, we have to consider several processes that associate with deglaciations and result in alterations of the North Atlantic circulation.

\subsection{Migration of the Arctic Front}

Works on the Quaternary have shown that surface water characteristics in the mid-latitude North Atlantic depend on the position of the oceanic fronts [64-66]. During glacial periods, the AF moved southward [36,55,60] and even reached the northern Iberian margin during some terminations and Heinrich events [67] (Figure 6b,c). This migration allowed cold, polar waters to expand into lower latitudes, recirculated by the NAC and the Portugal Current (PC). However, such wide amplitude migrations of the AF occurred mainly in relation to ice-sheets instabilities in the Northern Hemisphere [68]. Pulses of meltwater and icebergs from glaciers produced huge freshwater input in the high latitude ocean. This triggered important perturbations in the North Atlantic surface circulation and resulted in severe SST drops as far as the southernmost European margin $[56,57,59,60,67,69-75]$ (Figure 7).
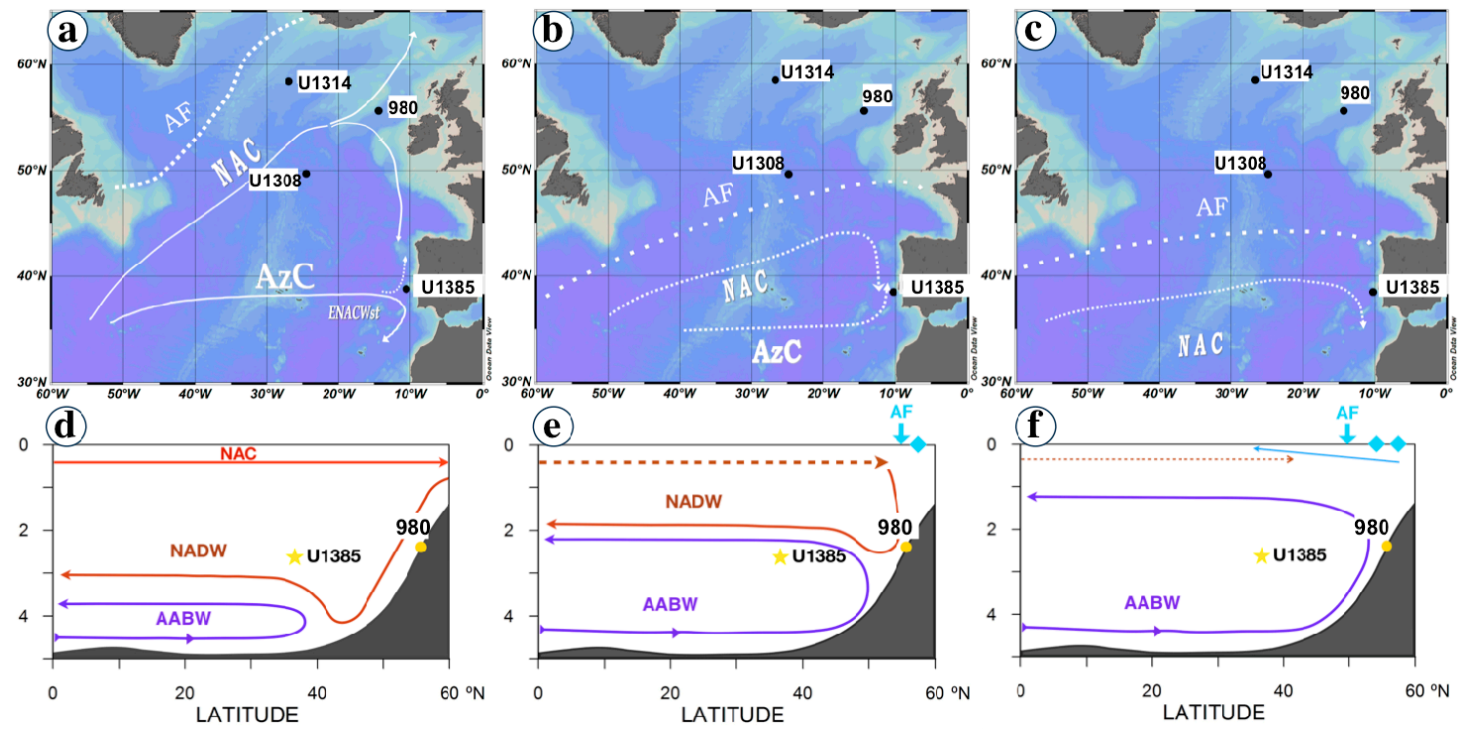

INTERGLACIALS

deep MOC / strong NAC

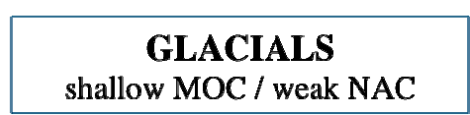

HE and TERMINATIONS no MOC / very weak NAC

Figure 6. In the upper panel, variations in the position of the artic front (AF) and paths of surface currents during; (a) interglacials, (b) glacials, and (c) terminations and Heinrich events. (References in the text). In the lower panel, meridional overturning circulation (MOC) modes along the Quaternary. (d) The position of the AF north of $60^{\circ} \mathrm{N}$ during interglacials favored a vigorous North Atlantic Current (NAC) and a deep MOC. (e) Iceberg surges and the southern position of the AF reduced the North Atlantic Deep Water (NADW) formation rate, which resulted in a shallow overturning cell and weak NAC. (f) Extremely weak surface circulation resulted from peak southward migrations of the AF and null NADW formation. Sites ODP-980 (55 $29^{\prime}$ N; $14^{\circ} 42^{\prime}$ W; $2168 \mathrm{~m}$ depth) and IODP-U1385 $\left(37^{\circ} 34^{\prime} \mathrm{N} ; 10^{\circ} 7^{\prime} \mathrm{W} ; 2589 \mathrm{~m}\right.$ depth) have been plotted to illustrate the position of NADW and Antarctic Bottom Water (AABW) (data from [36,60]). Cyan diamonds and line, in (e-f), represent icebergs and fresh-water, respectively, 
During glacial conditions, especially at times of glacial maxima, the southern position of the AF produced cold SST in most of the North Atlantic $\left(\sim 0.5-7^{\circ} \mathrm{C}\right)$. However, south of $37-39^{\circ} \mathrm{N}$, the European continental margin registered relatively warm SST (up to $17^{\circ} \mathrm{C}$ ) $[62,72,74,75]$ (Figure 7). This latitudinal gradient was caused by the eastwards diversion of the NAC that resulted from the advance of the AF (Figure $6 \mathrm{~b}$ ). The migration of the AF blocked the northward flow of the NAC and, in consequence, the arrival of warm water to the high-latitude European margin. At the same time, the southernmost European margin received warm water via the AzC [76] (Figure 6b). The extremely southern position of the AF during some peak glacial conditions produced the maximal diversion of the NAC, which acquired an almost pure west-east direction $[55,65,77]$. Only during deglaciations, major reorganizations of surface circulation occurred in the North Atlantic that promoted the southeastwards migration of the AF and allowed the expansion of very cold, polar waters along the Southwestern European margin, trespassing the $37-39^{\circ} \mathrm{N}$ threshold of glacial maxima (Figures $6 \mathrm{c}$ and 7 ).

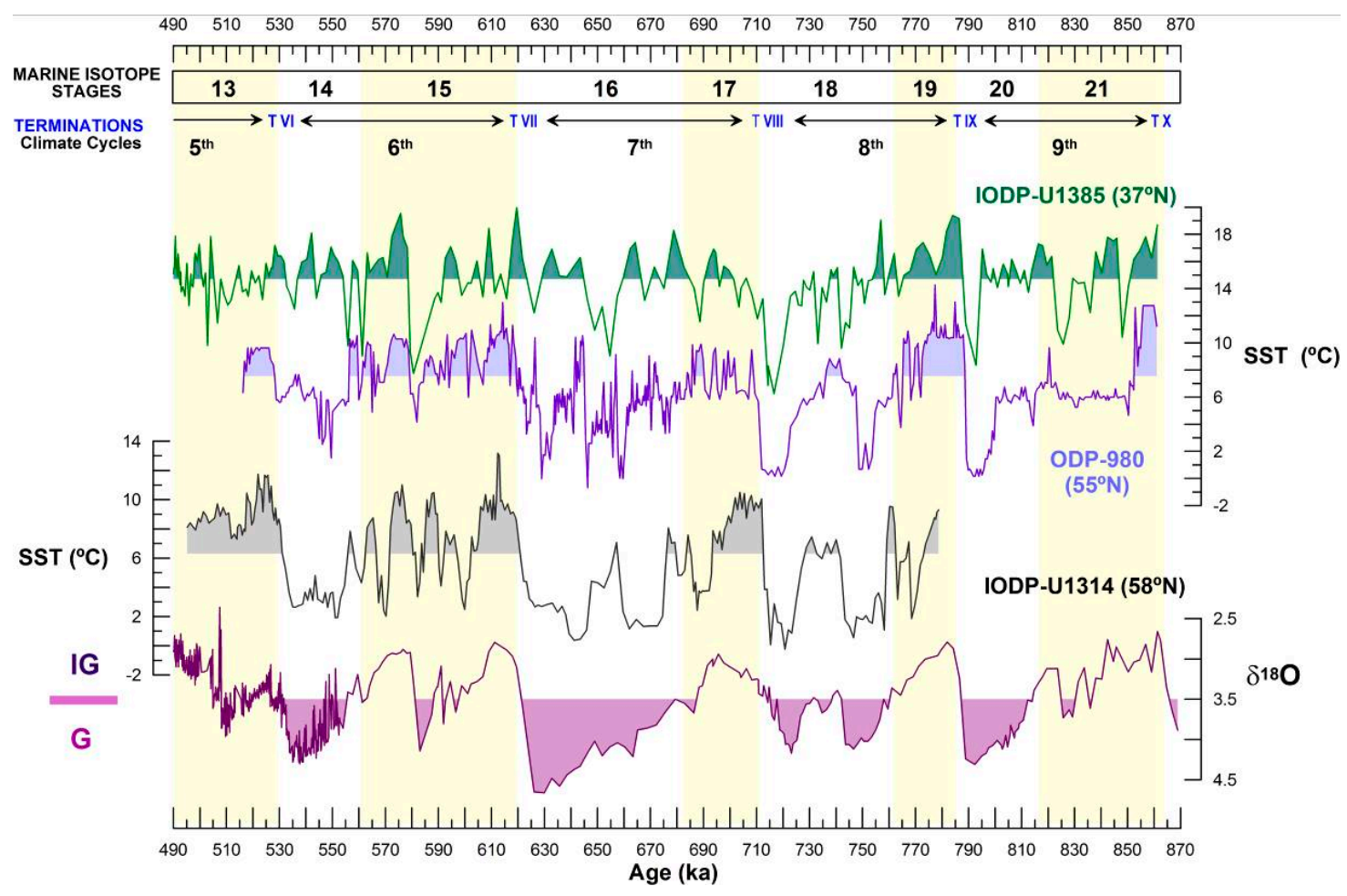

Figure 7. Latitudinal SST gradient in the North Atlantic between subpolar sites IODP-U1314 [78], ODP-980 [36], and the subtropical site IODP-U1385 [60] through middle Pleistocene climate cycles. Filled-in SST records highlight temperature above average for each site. Yellow bands highlight interglacial periods. The ice volume is indicated by $\delta^{18} \mathrm{O}$ [79]; purple fill shows the ice volume threshold separating glacial and interglacial stages. Marine isotope stages, terminations (in roman numerals), and climate cycles are represented on top. Yellow bands highlight interglacial stages.

After the ice-sheet-collapse events had finished and the input of very cold, low-salinity water stopped, the AF retreated northward again. The subtropical gyre rapidly resumed, and the strengthened NAC transported warm surface water along the European margin, which resulted in the remarkable warming episode registered after deglaciations. Prolonged and wide-amplitude deglaciations reduced drastically the extension of Northern Hemisphere ice-sheets and allowed a very northern position of the AF. This, in turn, permitted the northward migration of the AzF and the advection of warm water along the European margin (Figure 6a). The very rapid substitution of the masses of water that bathed the European margin during and immediately after deglaciations was registered by a sudden change in planktonic assemblages. Both in high and low latitudes, 
planktonic assemblages off Europe switched from polar to warm species (subtropical, in South Iberia) $[36,59,70,73,75,80]$.

\subsection{Weakening of the Atlantic Meridional Overturning Circulation}

During glacial stages, the North Atlantic circulation was severely affected not only at the surface, but also at depth (Figure $6 \mathrm{~b}, \mathrm{e}$ ). Slowdowns of the Atlantic meridional overturning circulation (AMOC) registered especially during deglaciations $[25,36,60]$ (Figure $6 \mathrm{f}$ ). This reduced AMOC was caused by a weakened North Atlantic Deep Water (NADW) formation, triggered by lower surface salinities in the subpolar North Atlantic that were the consequence of fresh water releases at the onset of ice-sheets retreat. As the AMOC is responsible for $\sim 50 \%$ of the total poleward advection of heat $[81,82]$, during these events of reduced AMOC, lower rates of heat were transferred to the North Atlantic and resulted in decreased SST from high to subtropical latitudes $[16,18,19,59,83]$.

Once the fresh-water perturbation produced by ice-sheets collapse finished, the NADW export abruptly resumed and the deep circulation switched to a northern-sourced regime [84] (Figure 6d). The reactivation of the AMOC strengthened the surface circulation in the North Atlantic, allowing the recirculation of warm water along the European margin. Such rapid reorganization of oceanographic conditions resulted in the remarkable warming that followed deglaciations $[58,60]$.

These oscillations of the AMOC rate can be recognized in the variation of the NADW / AABW boundary depth (Figure $6 \mathrm{~d}-\mathrm{f}$ ). The relative advance/retreat of the AABW with respect to the NADW is traceable in the carbon isotopes record from the North Atlantic bottom. As both masses of water have different carbon isotope composition, the $\delta^{13} \mathrm{C}$ indicates which of them is present at any given time (Figure 8).

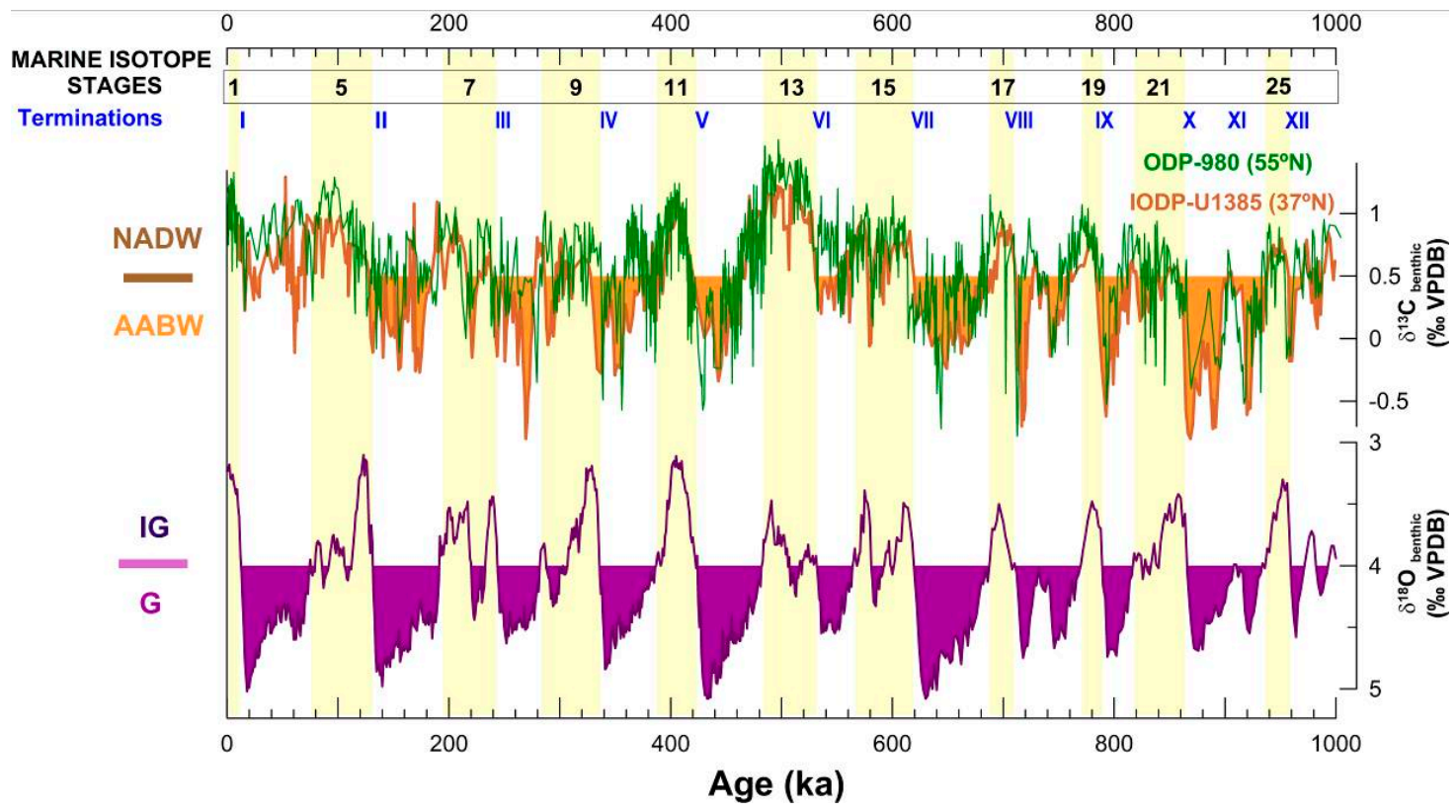

Figure 8. Atlantic meridional overturning circulation (AMOC) rate and origin of the deep water mass in the North Atlantic (northern-sourced NADW or southern-sourced AABW) along Pleistocene. In purple, $\delta^{18} \mathrm{O}[10]$ indicates ice volume; the fill shows the glacial/interglacial threshold. In brown, benthic $\delta^{13} \mathrm{C}$ from the mid-latitude site $\mathrm{U} 1385\left(37^{\circ} 34^{\prime} \mathrm{N} ; 10^{\circ} 7^{\prime} \mathrm{W} ; 2589 \mathrm{~m}\right.$ depth) [79]; orange fill shows $\delta^{13} \mathrm{C}$ values for AABW. In green, $\delta^{13} \mathrm{C}$ from the sub-polar site $980\left(55^{\circ} 29^{\prime} \mathrm{N} ; 14^{\circ} 42^{\prime} \mathrm{W} ; 2168 \mathrm{~m}\right.$ depth) [36]. Site 980 generally registers higher $\delta^{13} \mathrm{C}$ than site $\mathrm{U} 1385$ because the surface water sinks in this region to form NADW. The exceptional events when $\delta^{13} \mathrm{C}$ is lower in 980 than in U1385 occur as consequence of the migration of the sinking area south from site 980 . 
The AMOC rate was not the same in all glacial maxima or in all deglaciations. During some of them, an active but shallow overturning cell maintained, exporting northern-sourced water at intermediate depth; while the abyssal North Atlantic was occupied by AABW [85,86] (Figure 6e). Strong sinking rates, although relatively superficial, would allow the recirculation of warm surface water along the European margin and prevent severe thermal drops. This is what happened during $\mathrm{T}$ VII, VI, and I [76,77,84,87].

Episodes of weakest AMOC happened during ice rafting events (Heinrich-type events) that coincided with Terminations. Several works have demonstrated the relationship between ice-sheets instabilities - which resulted in iceberg calving and dispersal—and cooling events along the western European margin. Such events were accompanied by high percentages of the polar foraminifer Neogloboquadrina pachyderma, and by layers of ice-rafted debris (IRD). During most deglaciations, IRD layers were recorded even at the southernmost European margin $[56,57,60,68,69]$. Continuous massive surges and melting of iceberg during deglaciations increased the freshwater flow into the subpolar North Atlantic. This drastically reduced the export of NADW $[18,88]$ and resulted in the spread of sea ice and polar waters along the European margin, with the associated SST drop $[58,89,90]$.

Heinrich events happening at times of particularly high ice volume would produce the complete shutdown of the NADW formation, as studies for the last glacial demonstrate [84] (Figure 6f). Nevertheless, it is thought that this mechanism could have also worked during the Pleistocene, as deduced from records of the southernmost European margin (Figure 5). Here, the most pronounced cooling events were associated to Heinrich-type events that coincided with Terminations either with maximal ice coverage, like T IX, of very prolonged in time, like T VIII [60].

\section{Climate Variations in Inland Europe}

\subsection{Influence of NAO-Index Variations in the European Climate}

The NAO is coupled with the trade winds that greatly influence the inland climate. This index determines both the wind-speed variability and winter precipitation levels $[41,91,92]$ (Figure 9). It also impacts on the mean temperature of the region, as well as on maximum (Tmax) and minimum (Tmin) thermal values, especially in winter. Central and Northern Europe records Tmax anomalies up to $1.8^{\circ} \mathrm{C}$ during winter months with high NAO index, and Tmin anomalies from -0.9 to $-1.8^{\circ} \mathrm{C}$ in association with low NAO index [49].

During $\mathrm{NAO}^{+}$phases, the strengthened westerlies advect moist warm air to the Northeast, which results in warming and increased precipitation over Northern Europe. With values of the NAO index $>1.0$, this anomalous warmth extends to Central Europe and even as far south as the Iberian Peninsula and the Balkans. The observed trend towards a $\mathrm{NAO}^{+}$can explain the recent winter warming over Europe [93]. On the other hand, an anomalous anticyclonic circulation develops over Central Europe and the Iberian Peninsula during $\mathrm{NAO}^{+}$winters. This reduces the cloud cover in these regions and, subsequently, the precipitation (Figure 9a,c).

During NAO$^{-}$phases, a strong, anomalous, southern flow from the Arctic advects very cold air into Northern Europe, causing negative Tmin anomalies [49]. This impact on the Tmin rather than on the Tmax is related with the lack of clouds that corresponds to the typical high pressure cell, and anticyclonic circulation that characterise the $\mathrm{NAO}^{-}$phase over North and Central Europe (Figure 9b). In this sense, the lack of clouds during daytime allows increased solar radiation, enough to modulate the cooling effect of the advected polar air. During the night, the clear sky favors the loss of heat through long-wave radiation, further lowering the Tmin.

Variations of the NAO index can also trigger climate changes over continental Europe that have further consequences. In this line, the decreased Mediterranean Sea-level observed from the 1960s to the 1990s has been explained, at least in a significant proportion, by the strengthening of the NAO over the period. A strong NAO would produce atmospheric pressure anomalies that would result in 
increased evaporation and decreased precipitation over the Mediterranean hydrographic basin [94] (Figure 9c).
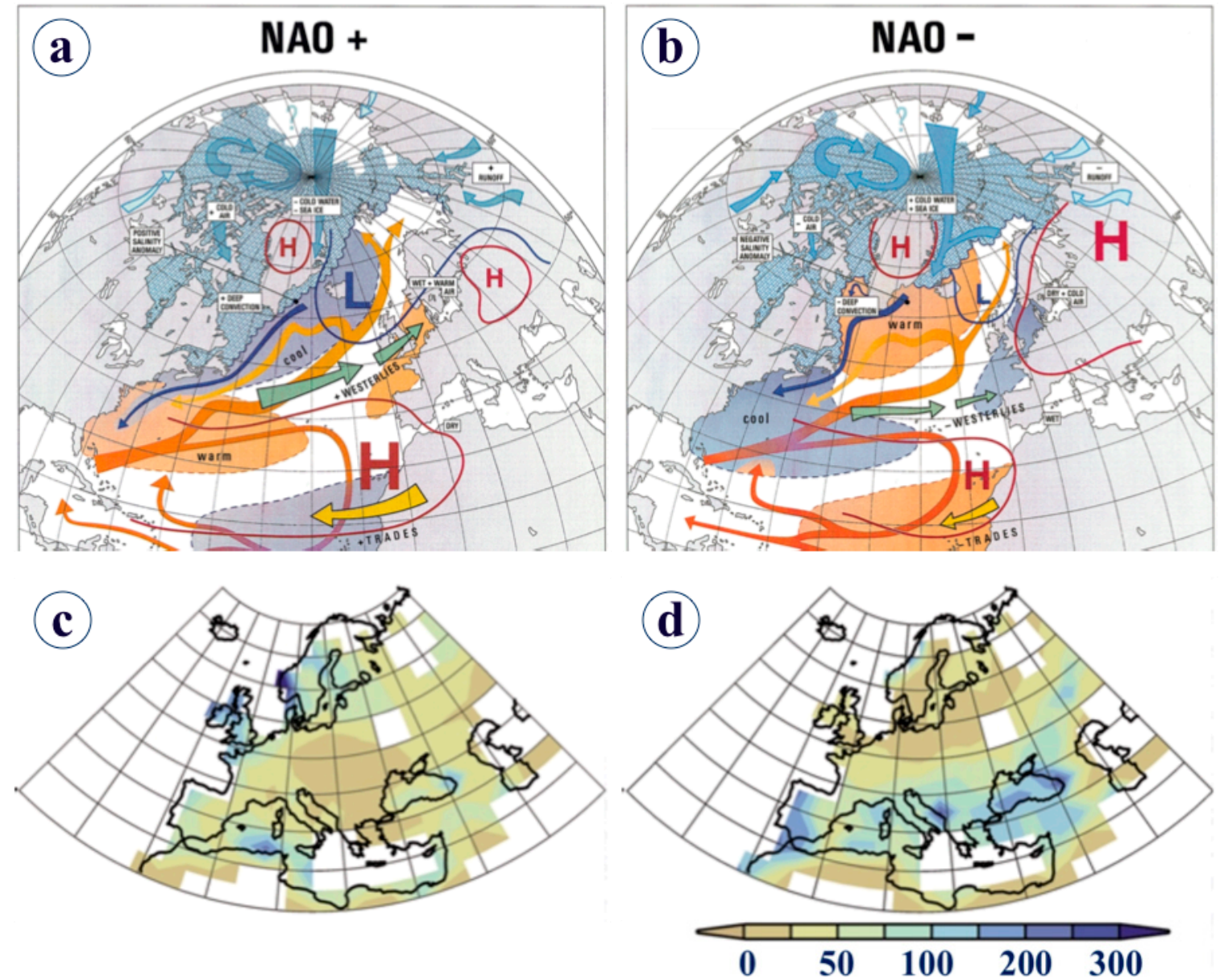

Figure 9. Atmospheric and oceanic circulation $(\mathbf{a}, \mathbf{b})$, and precipitation $((\mathbf{c}, \mathbf{d}), \mathrm{mm})$ for the two modes of the NAO index. In (a,b) sea-ice extension, cold, and warm SST are plotted in cyan, blue, and orange, respectively. The thickness of arrows represents the strength of the winds. Data from $[41,95,96]$.

To confidently extrapolate present-day ocean-ice-atmosphere interactions and interpret Quaternary climate dynamics, it is imperative to study lower-than-decadal-frequency climate variability. In this line, several authors reconstructed historical variations of the NAO index and other atmospheric conditions, based on the study of tree-ring data, Greenland ice cores, stalagmite growth-rate, and others [97-107]. Especially interesting is [108], which used driftwood records and a dynamic-thermodynamic sea-ice model to reconstruct high-latitude atmospheric circulation during the whole Holocene. According to their results, since the last deglaciation, the average atmosphere-ocean system in the North Atlantic shifted abruptly between two main modes of centennial to millennial duration. The first mode is characterized by negative NAO and large ice export. The second one is more similar to the present-day trend, with a positive NAO and low ice export. These swings in the atmosphere-ocean system produced variations in the wind speed and direction, in the heat and humidity transfer from the North Atlantic to Europe, and in the storm paths and intensity. In summary, they were responsible for climatic variations in the Eurasian continent, which were registered in tree rings, historical records of precipitation, etc. When extrapolating to previous glacial/interglacial transitions, similar shifts in the North Atlantic-Europe climate system must have happened, but the rapid changes were damped by the slower response of vegetation - the main proxy used to study past continental climate. Because of this, the response of inland climate to glacial-interglacial changes 
is mainly recorded by a high-amplitude shift between the glacial-maximum-mode of vegetation to the interglacial-optimum-mode [109-113]. Nevertheless, the transition between modes must have occurred by a succession of centennial-scale climate oscillations of lesser amplitude, similar to the present interglacial, rather than by one and only abrupt shift (Figure 10).

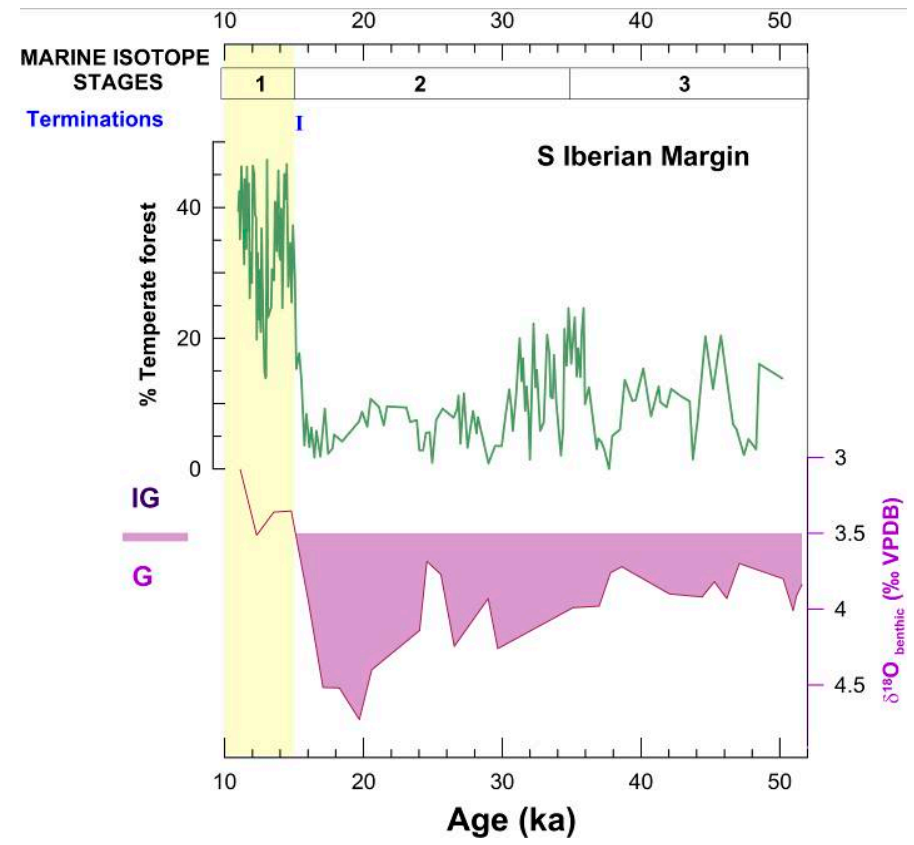

Figure 10. Shift between vegetation modes during the last glacial/interglacial transition, as recorded in the southern Iberian margin. In purple, benthic $\delta^{18} \mathrm{O}$ [79] indicates ice volume; the fill shows the glacial/interglacial threshold. In green, pollen from trees associated to temperate forest [114]. Marine isotope stages and terminations (in roman numerals) are represented on top. The yellow band highlights the interglacial stage.

\subsection{Influence of Sea Surface Temperature in the European Climate Variations}

Thermal variations in the ocean can affect inland climate via NAO alterations. Numerous studies in the present-day ocean clearly demonstrate that the NAO signal is connected with preceding SST variations in the North Atlantic [115-118], and it is even modulated by them at a $\sim 60$ year timescale [119]. This connection between North Atlantic SST anomalies and atmospheric circulation has been further supported by models [120-122] and explained via evaporation, precipitation, and atmospheric heating processes over the ocean that lead to changes of temperature and precipitation inland [120]. In this line, variations of SST recorded in the North Atlantic during the last two centuries had important consequences in European climate, especially in precipitation rates [123]. Inter-annual changes in sea/land temperature co-variances are also related with NAO [124].

The tropical and subtropical North Atlantic is the most important region for this connection between ocean and inland climate, as SST here co-varies with trade-winds fluctuations $[45,125]$. This co-variance is explained because the trade winds are influenced by shifts in the latitudinal position of the ITCZ, as fossil pollen records from Southern Europe reveal [110]. Nevertheless, at a decadal timescale, thermal variations in the subpolar ocean also influence inland climate, as the increase in SST in the Labrador Sea was paired by positive anomalies in air pressure over Greenland. That is, a weaker-than-normal Iceland Low and an associated decrease of the NAO resulting from the southward diversion of the storm tracks [96].

This connection between SST and inland climate is not limited to the Holocene or to similar interglacial stages, as it also happened during the glacials. Records from Iberia and the Iberian margin for the two last glaciations show that percentage variations of the temperate vegetation closely 
mirrored the planktonic isotopic signal [112,114] (Figure 11). This suggests the synchronous response of vegetation to SST variability. Temperate arboreal communities expanded coinciding with interstadials (warm intervals), registered by both SST records and Greenland ice cores (Figure 11). Steppe vegetation, in turn, was dominant during stadials $[111,126]$. A similar covariance SST- inland climate was observed in speleothems from France [127].

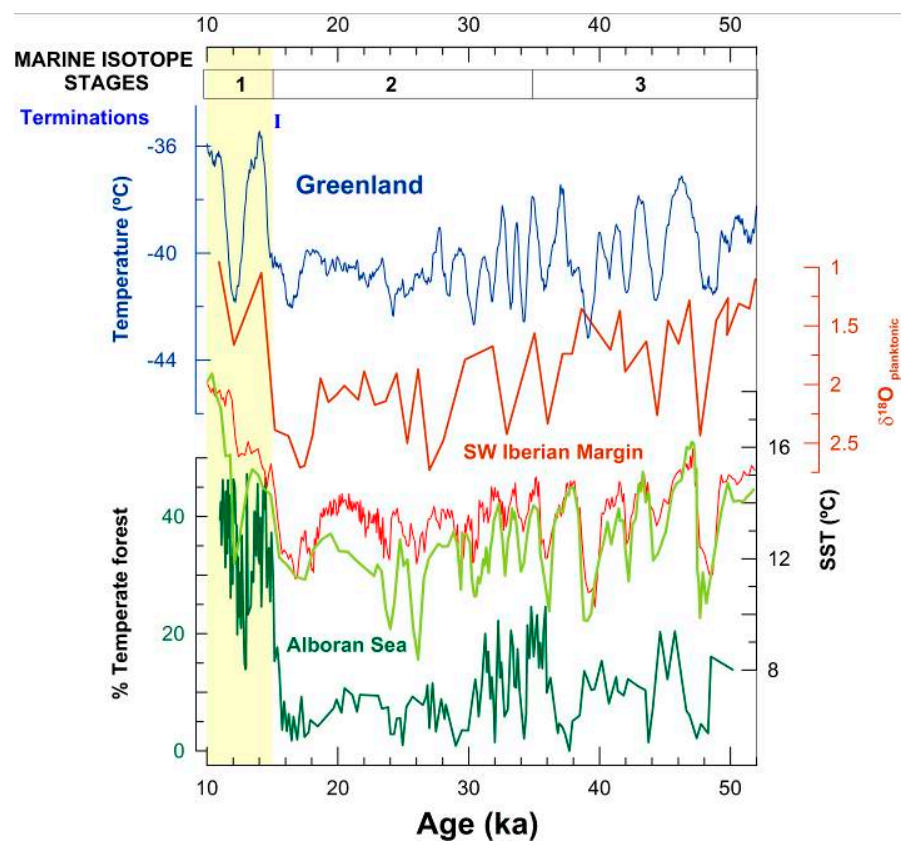

Figure 11. Climate records from the Iberian margin compared with Greenland temperature for the last 52,000 years. Variations of temperate forest recorded in the Alboran Sea (dark green) [114] correlate well with SST from both the Alboran Sea (light green) and the Southwest Iberian margin (red) [56], with the planktonic $\delta^{18} \mathrm{O}$ from the SW Iberian margin (dark red) [79] and with temperature over Greenland (blue) [37]. Marine isotope stages and terminations (in roman numerals) are represented on top. The yellow band highlights the interglacial stage.

The main thermal oscillations in the European margin occurred in association with deglaciations, as explained in previous sections. Very cold SST, especially, had a deep impact in the southern European climate. Here, the moisture-requiring vegetation collapsed at the beginning of deglaciations and was substituted by less demanding steppe communities. Once the deglaciation finished and the SST had risen, moisture-requiring vegetation expanded again [112,126,128-130] (Figure 11).

\subsection{Influence of the Thermohaline Circulation}

The AMOC is responsible for controlling the heat transport from low to high latitudes $[82,85]$ and modulating climate [131,132]. Therefore, alterations in the NADW formation rate have important impacts in climate. In this line, the inter-decadal variability of the NAO has been explained by variations in the thermohaline circulation [133]. At times of weak AMOC, very cold waters spread over the subpolar North Atlantic, resulting in SST anomalies. Such anomalies transfer from the ocean to the air and induce atmospheric thermal decreases not only over the North Atlantic region but also over Northern Eurasia and Northwestern Europe [134]. Furthermore, this cold pool over the subpolar North Atlantic affects the Greenland high and Icelandic low-pressure cells, altering the atmospheric circulation and the NAO index $[96,118]$. The influence of the AMOC in the NAO also works through the variation of the Gulf Stream path. Though the connecting mechanism is not yet well understood, it appears that the NAO dynamics correlates with the annual mean latitudinal position of the Gulf Stream [135]. It has been demonstrated that the axis of the subtropical gyre migrates southwards as 
consequence of reduced NADW formation and the associated spread of cold water over the North Atlantic [136].

During the Quaternary, main alterations of AMOC were associated with deglaciations and stadial-interstadial transitions [25,137-139]. At these times, climate in most of Europe became very cold, dry, and windy in the southern margin. This interpretation is supported by pollen records from the Balkan to the Iberian Peninsulas, which show an increase of steppe vegetation at the expense of temperate forest during the last deglaciation $[129,140]$, which indicates a climate shift towards colder and dryer conditions.

\subsection{Influence of the Ice Sheet Extension and Volume}

Sea-ice coverage influences the heat flow to the atmosphere and, in consequence, can modify the atmospheric circulation. Studies of trends in the modern ocean show that decadal sea-ice variability is strongly coupled with the NAO index $[43,141]$. Particularly, the sea-ice extension in Nordic and Baltic seas correlates negatively with the NAO index, while in the Labrador Sea, it is positively correlated [142-144]. Though this NAO-sea-ice-coverage interaction is clear, it does not mean that variability of the European inland climate can be correlated to the present-day sea-ice surface. In fact, studies of southern European climate regimes during previous interglacials-measured as forest development-showed that forest extent was not related with residual ice volume but with other climate forcing, like the amplitude of insolation [145]. Nevertheless, during glacial intervals, the correlation between ice-sheets volume and forest extent was very close. This suggests that different climate forcing worked in inland Europe during glacial and interglacial stages.

The ice volume, as well as the sea-ice extension and location, has also an influence on continental climate. The global ice volume during glacials, and especially the Northern Hemisphere ice-sheets, determine the strength of the following interglacial. That is, a very warm and rapid interglacial follows a strong (in ice volume and cold temperature) glacial maximum and vice-versa. A greater deglaciation corresponds also to stronger glacials [4]. Such a connection has been identified for all the Terminations since $800 \mathrm{ka}$, as well as for other important decreases of ice-volume that occurred during both glacial and interglacial periods. The explanation is that deglaciations occur when astronomical forcing combined with ice-sheet volume reach a threshold. During periods of weak forcing, a greater ice-sheet extension is required for a deglaciation to occur. As glaciations only initiate as consequence of astronomical forcing, these periods of weak forcing will allow a greater deglaciation and, in consequence, a stronger interglacial [146].

During glacial stages, climate in Southern Europe was generally cold and dry, its climatic severity depending on the global ice volume and particularly, on the Northern Hemisphere's $[113,145]$. Relatively high percentages of semi-desert vegetation were recorded when ice volume was great, as during glacials MIS 12, MIS 6, MIS 4, and MIS 2. Opposite to this, less severe glacial periods were marked by higher forest coverage, which require warmer and wetter conditions $[112,134,147]$ (Figure 10). During interglacials, climate in these regions became milder and more humid. The temperature rise from the preceding glacial depended mainly on the amplitude of the deglaciation. That is, the temperature during interglacial optima was directly proportional to the ice volume during the previous glacial period. Such climate changes were mainly recorded by the rapid increase of temperate and Mediterranean arboreal pollen percentage in Southern Europe [109-113] as well as by speleothems $[103,148]$.

\section{Conclusions}

The most severe and drastic climate changes in European climate during the Quaternary occurred in association with deglaciations as a consequence of major oceanographic reorganisations that affected atmospheric circulation and ocean-atmosphere heat-flow, which led to the variation of temperature and precipitation inland. During deglaciations, profound changes in the North Atlantic circulation resulted in reduced northward flow of warmth, which promoted the southeastward migration of 
the Arctic front and the expansion of cold subpolar waters along the European margin, passing the $37-39^{\circ} \mathrm{N}$ threshold of glacials. This resulted in the deepest cooling registered in the region during the Quaternary, including the most severe glacial maxima. The amplitude and duration of these cooling episodes were directly related with the magnitude of the ice volume reduction. After ice-sheet collapse had finished, and once the AF retreated northward again, the subtropical gyre resumed and the NAC strengthened, advecting warm surface water along the European margin. This resulted in the sudden and wide-amplitude warming that was recorded after deglaciations, and that marked the climate optimum of the succeeding interglacial. This sudden substitution of water masses bathing both high and low latitude North Atlantic during and immediately after deglaciations was registered by a very rapid change in planktonic flora and fauna that switched from polar to warm/subtropical assemblages.

Decreased SST from high to subtropical-latitude North Atlantic were the consequence of slowdowns of the AMOC that were caused by a weakened NADW formation and were triggered by low salinities in the subpolar North Atlantic due to fresh water releases at the onset of Northern Hemisphere ice sheets retreat. Nevertheless, the rate of AMOC was not the same in all deglaciations-during some of them, an active but shallow overturning cell maintained, exporting northern-sourced water at intermediate depth. This mechanism can counteract the effect of deglaciation in decreasing SST and be responsible for the anomalously weak cooling recorded during some of the largest deglaciations of the whole Quaternary, like T VII. Complete shutdowns of NADW formation only occurred during Heinrich-type events coinciding with deglaciations either with maximal ice coverage-like T IX—or very prolonged in time-like T VIII, when continuous massive surges and melting of iceberg increased the freshwater flow. Such events resulted in the most pronounced cooling. Once the fresh water perturbation produced by ice sheets collapse finished, the NADW export abruptly resumed and the deep circulation switched to a northern-sourced regime. The reactivation of the AMOC strengthened the surface circulation in the North Atlantic. Such rapid reorganization of oceanographic conditions resulted in the remarkable warming that followed deglaciations.

Variations in SST and other oceanographic changes affected atmospheric circulation, ocean-atmosphere heat-flow, evaporation, and precipitation rates, which led to variation of temperature and precipitation inland. Covariance between SST and European inland climate signals was especially observed in speleothems from France and vegetation communities in Southern Europe. During deglaciations, climate in Southern Europe was cold, dry, and windy, which caused the substitution of temperate, moisture-requiring vegetation for less-demanding steppe communities. Once deglaciation had finished, the climate in these regions became milder and more humid, the temperature rise depending mainly on the amplitude of the deglaciation. Nevertheless, the climate change from glacial to interglacial stages influenced mid-latitude European climate not merely by switching between two different climate regimes but by changing its main driving forcing. During glacials, climatic severity in Southern Europe depended on the global ice volume; the forest extent being closely correlated with the North Hemisphere ice sheet extension. During interglacials, forest coverage was not related with residual ice volume but with other climate forcing, like the amplitude of insolation.

Funding: This research received no external funding.

Acknowledgments: The author wants to acknowledge the useful comments and suggestions from three anonymous referees that greatly contributed to improve the present manuscript.

Conflicts of Interest: The author declares no conflict of interest.

\section{References}

1. Mercer, J. Simultaneous climatic change in both Hemispheres and similar bipolar interglacial warming: Evidence and implications. In Climate Processes and Climate Sensitivity, Geophysical Monograph 29; Ewing, M., Ed.; American Geophysical Union: Washington, DC, USA, 1984; pp. 307-313.

2. Berger, A.; Li, X.S.; Loutre, M.F. Modelling northern hemisphere ice volume over the last 3 Ma. Quat. Sci. Rev. 1999, 18, 1-11. [CrossRef] 
3. Lisiecki, L.E.; Raymo, M.E. Plio-Pleostocene climate evolution: Trends and transitions in glacial cycle dynamics. Quat. Sci. Rev. 2007, 26, 56-69. [CrossRef]

4. Lang, N.; Wolff, E.W. Interglacial and glacial variability from the last $800 \mathrm{ka}$ in marine, ice and terrestrial archives. Clim. Past 2011, 7, 361-380. [CrossRef]

5. Raynaud, D.; Loutre, M.F.; Ritz, C.; Chappellaz, J.; Barnola, J.M.; Jouzel, J.; Lipenkov, V.Y.; Petit, J.R.; Vimeux, F. Marine Isotope Stage (MIS) 11 in the Vostok ice core: $\mathrm{CO}_{2}$ forcing and stability of East Antarctica. Geophys. Monog. 2003, 137, 27-40.

6. Milankovitch, M. Canon of insolation and the ice-age problem. Roy. Serb. Sci. Spec. Publ. Sect. Math. Nat. Sci. 1941, 33, 633.

7. Imbrie, J.; Boyle, E.A.; Clemens, S.C.; Duffy, A.; Howard, W.R.; Kukla, G.; Kutzbach, J.; Martinson, D.G.; McIntyre, A.; Mix, A.C.; et al. On the Structure and Origin of Major Glaciation Cycles 1. Linear responses to Milankovitch forcing. Paleoceanography 1992, 7, 701-738. [CrossRef]

8. Ruddiman, W.F. Ice-driven $\mathrm{CO}_{2}$ feedback on ice volume. Clim. Past 2006, 2, 43-55. [CrossRef]

9. Huybers, P. Glacial variability over the last two million years: An extended depth-derived agemodel, continuous obliquity pacing and the Pleistocene progression. Quat. Sci. Rev. 2007, 26, 37-55. [CrossRef]

10. Lisiecki, L.E.; Raymo, M.E. A Pliocene-Pleistocene stack of 57 globally distributed benthic $\mathrm{d}^{18} \mathrm{O}$ records. Paleoceanography 2005, 20, PA1003.

11. Laskar, J.; Robutel, P.; Joutel, F.; Gastineau, M.; Correia, A.C.M.; Levrard, B. A long- term numerical solution for the insolation quantities of the Earth. Astron. Astrophys. 2004, 428, 1. [CrossRef]

12. Shackleton, N.J.; Pisias, N.G. Atmospheric carbon dioxide, orbital forcing and climate. In The Carbon Cycle and Atmospheric $\mathrm{CO}_{2}$ : Natural Variations, Archean to Present; Sundquist, E.T., Broecker, W.S., Eds.; American Geophysical Union: Washington, DC, USA, 1985.

13. Kennett, J.P.; Cannariato, K.G.; Hendy, I.L.; Behl, R.J. Carbon isotopic evidence for methane hydrate instablity during Quaternary interstadials. Science 2000, 288, 128-133. [CrossRef] [PubMed]

14. Ruddiman, W.F. Orbital insolation, ice volume and greenhouse gases. Quat. Sci. Rev. 2003, 22, 1597-1629. [CrossRef]

15. Toggweiler, J.R.; Russell, J.L.; Carson, S.R. Midlatitude westerlies, atmospheric $\mathrm{CO}_{2}$ and climate change during the ice ages. Paleoceanography 2006, 21. [CrossRef]

16. Broecker, W.S.; Kennett, J.P.; Flower, B.P.; Teller, J.T.; Trumbore, S.; Bonani, G.; Wolfli, W. Routing of meltwater from the Laurentide Ice Sheet during the Younger Dryas cold episode. Nature 1989, 341, 318-321. [CrossRef]

17. Raymo, M.E.; Oppo, D.W.; Curry, W.V. The mid-Pleistocene climate transition: A deep sea carbon isotopic perspective. Paleoceanography 1997, 12, 546-559. [CrossRef]

18. McManus, J.F.; Francois, R.; Gherardi, J.; Keigwin, L.; Brown-Leger, S. Collapse and rapid resumption of Atlantic meridional circulation linked to deglacial climate change. Nature 2004, 428, 834-837. [CrossRef] [PubMed]

19. Pisias, N.G.; Clark, P.U.; Brook, E.J. Modes of global climate variability during Marine Isotope Stage 3 (60-26 ka). J. Clim. 2010, 23, 1581-1588. [CrossRef]

20. Imbrie, J.; Berger, A.; Boyle, E.A.; Clemens, S.C.; Duffy, A.; Howard, W.R.; Kukla, G.; Kutzbach, J.; Martinson, D.G.; McIntyre, A.; et al. On the structure and origin of major glaciation cycles: 2. The 100,000-year cycle. Paleoceanography 1993, 8, 699-735. [CrossRef]

21. Denton, G.H.; Anderson, R.F.; Toggweiler, J.R.; Edwards, R.L.; Schaefer, J.M.; Putnam, A.E. The Last Glacial Termination. Science 2010, 328, 1652-1656. [CrossRef]

22. Heinrich, H. Origin and consequences of cyclic ice rafting in the Northeast Atlantic Ocean during the past 130,000 yrs. Quat. Res. 1988, 29, 142-152. [CrossRef]

23. Broecker, W.S. Massive iceberg discharges as triggers for global climate change. Nature 1994, 372, $421-424$. [CrossRef]

24. Cortijo, E.; Yiou, P.; Labeyrie, L.; Cremer, M. Sedimentary record of rapid climatic variability in the North Atlantic Ocean during the last glacial cycle. Paleoceanography 1995, 10, 911-926. [CrossRef]

25. Hodell, D.A.; Channell, J.E.T.; Curtis, J.H.; Romero, O.E.; Röhl, U. Onset of "Hudson Strait" Heinrich events in the eastern North Atlantic at the end of the middle Pleistocene transition ( 640 ka)? Paleoceanography 2008, 23. [CrossRef] 
26. Channell, J.E.T.; Hodell, D.A.; Romero, O.; Hillaire-Marcel, C.; de Vernal, A.; Stoner, J.S.; Mazaud, A. Roehl. IODP Site U1302-U1303 (Orphan Knoll): Correlation of Brunhes detrital-layer stratigraphy into the North Atlantic. Earth Planet. Sci. Letts. 2012, 317-318, 218-230. [CrossRef]

27. Broecker, W.S.; Bond, G.; Klas, M.; Clark, E.; McManus, J. Origin of the nothern Atlantic's Heinrich events. Clim. Dyn. 1992, 6, 265-273. [CrossRef]

28. Bond, G.C.; Lotti, R. Iceberg discharges into the North Atlantic on millennial time scales during the last glaciation. Science 1995, 267, 1005-1010. [CrossRef] [PubMed]

29. Stuiver, M.; Grootes, P.M. GISP2 oxygen isotope ratios. Quat. Res. 2000, 53, 277-284. [CrossRef]

30. Huber, C.; Leuenberger, M.; Spahni, R.; Flückiger, J.; Schwander, J.; Stocker, T.F.; Johnsen, S.; Landais, A.; Jouzel, J. Isotope calibrated Greenland temperature record over marine isotope stage 3 and its relation to $\mathrm{CH}_{4}$. Earth Planet. Sci. Lett. 2006, 243, 504-519. [CrossRef]

31. Dansgaard, W.; Johnsen, S.J.; Clausen, H.B.; Dahl-Jensen, D.; Gundestrup, N.S.; Hammer, C.U.; Hvidberg, C.S.; Steffensen, J.P.; Sveinbjörnsdottir, A.E.; Jouzel, J.; et al. Evidence for general instability of past climate from a $250 \mathrm{kyr}$ ice-core record. Nature 1993, 364, 218-220. [CrossRef]

32. Grootes, P.M.; Stuiver, M.; White, J.W.C.; Johnsen, S.; Jouzel, J. Comparison of oxigen isotope records from the GISP2 and GRIP Greenland ice cores. Nature 1993, 255, 522-554.

33. Broecker, W.S.; Bond, G.; Millie, K.; Geotges, B.; Willy, W. A salt oscillator in the glacial Atlantic? 1, The concept. Paleoceanography 1990, 5, 469-477. [CrossRef]

34. Broecker, W.S.; Peteet, D.M.; Rind, D. Does the ocean-atmosphere system have more than one stable mode of operation? Nature 1985, 315, 21-26. [CrossRef]

35. Bond, G.; Heinrich, H.; Broecker, W.; Labeyrie, L.; McManus, J.; Andrews, J.; Huon, S.; Jantschik, R.; Clasen, S.; Simet, C.; et al. Evidence for massive discharges of icebergs into the North Atlantic Ocean during the last glacial period. Nature 1992, 360, 245-249. [CrossRef]

36. Wright, A.K.; Flower, B.P. Surface and deep ocean circulation in the subpolar North Atlantic during the mid-Pleistocene revolution. Paleoceanography 2002, 17, 1068. [CrossRef]

37. Barker, S.; Knorr, G.; Edwards, L.; Parrenin, F.; Putnam, A.E.; Skinner, L.C.; Wolff, E.; Ziegler, M. 800,000 years of abrupt climate variability. Science 2011, 334, 347. [CrossRef] [PubMed]

38. Bjerknes, J. Atlantic air-sea interaction. Adv. Geophys. 1964, 10, 1-82.

39. Maze, J.P.; Arhan, M.; Mercier, H. Volume budget of the eastern boundary layer off the Iberian Peninsula. Deep Sea Res. Part I Oceanog. Res. Pap. 1997, 44, 1543-1574. [CrossRef]

40. Coelho, H.; Neves, T.; White, M.; Leitpo, P.; Santos, A. A model for ocean circulation on the Iberian coast. J. Mar. Syst. 2002, 32, 181-198. [CrossRef]

41. Hurrell, J.W. Decadal trends in the North Atlantic Oscillation: Regional temperatures and precipitation. Science 1995, 269, 676-679. [CrossRef] [PubMed]

42. Dickson, R.; Lazier, J.; Meinke, J.; Thines, P.; Swift, J. Long term coordinated changes in the convective activity of the North Atlantic. Progr. Oceanogr. 1996, 38, 241-295. [CrossRef]

43. Deser, C.; Walsh, J.E.; Timlin, M.S. Arctic sea ice variability on the context of recent atmospheric circulation trends. J. Clim. 2000, 13, 617-633. [CrossRef]

44. Schieller, A.; Milkolajewicz, U.; Voss, R. The stability of North Atlantic thermohaline circulation in a coupled ocean-atmosphere general circulation model. Clim. Dyn. 1997, 13, 325-347. [CrossRef]

45. Black, D.E.; Peterson, L.C.; Overpeck, J.T.; Kaplan, A.; Evans, M.N.; Kashgarian, M. Eight centuries of North Atlantic Ocean variability. Science 1999, 286, 1709-1713. [CrossRef] [PubMed]

46. Peterson, L.C.; Haug, G.H.; Hughen, K.A.; Tohl, U. Rapid changes in the tropical hydrologic cycle of the tropical Atlantic during the last glacial. Science 2000, 290, 1947-1951. [CrossRef] [PubMed]

47. Schmidt, M.W.; Spero, H.J.; Lea, D.W. Links between salinity variation in the Caribbean and North Atlantic thermohaline circulation. Nature 2004, 428, 160-163. [CrossRef] [PubMed]

48. Rodo, W.; Baert, E.; Comin, F.A. Variations in seasonal rainfall in southern Europe during the present century: Relationships with the North Atlantic Oscillation and the El Niño-Southern Oscillation. Clim. Dyn. 1997, 13, 275-284. [CrossRef]

49. Trigo, R.M.; Osborn, T.J.; Corte-Real, J.M. The North Atlantic Oscillation influence on Europe: Climate impacts and associated physical mechanisms. Clim. Res. 2002, 20, 9-17. [CrossRef]

50. McCartney, M.S.; Talley, L.D. The Subpolar Mode Water of the North Atlantic Ocean. J. Phys. Oceanogr. 1982, 12, 1169-1188. [CrossRef] 
51. Brambilla, E.; Talley, L.D. Subpolar Mode Water in the northeastern Atlantic: 1. Averaged properties and mean circulation. J. Geophys. Res. 2008, 113, C04025. [CrossRef]

52. Rios, A.F.; Perez, F.F.; Fraga, F. Water Masses in the Upper and Middle North-Atlantic Ocean East of the Azores. Deep Sea Res. Part A 1992, 39, 645-658. [CrossRef]

53. Peliz, A.; Dubert, J.; Santos, A.M.P.; Oliveira, P.B.; Le Cann, B. Winter upper ocean circulation in the Western Iberian Basin-Fronts, eddies and poleward flows: An overview. Deep Sea Res. Part I 2005, 52, 621-646. [CrossRef]

54. Fiúza, A.F.G.; Hamann, M.; Ambar, I.; Díaz del Río, G.; González, N.; Cabanas, J.M. Water masses and their circulation off western Iberia during May 1993. Deep Sea Res. Part I 1998, 45, 1127-1160. [CrossRef]

55. Pflaumann, U.; Sarnthein, M.; Chapman, M.; de Abreu, L.; Funnell, B.; Huels, M.; Kiefer, T.; Maslin, M. Glacial North Atlantic: Sea-surface conditions reconstructed by GLAMAP 2000. Paleoceanography 2003, 18, 1065. [CrossRef]

56. Martrat, B.; Grimalt, J.O.; Shackleton, N.J.; de Abreu, L.; Hutterli, M.A.; Stocker, T.F. Four Climate Cycles of Recurring Deep and Surface Water Destabilizations on the Iberian Margin. Science 2007, 317, 502-507. [CrossRef] [PubMed]

57. Rodrigues, T.; Voelker, A.H.L.; Grimalt, J.O.; Abrantes, F.; Naughton, F. Iberian Margin sea surface temperature during MIS15 to 9 (580-300 ka): Glacial suborbital variability versus interglacial stability. Paleoceanography 2011, 26, 1-16. [CrossRef]

58. Martin-Garcia, G.M. The Influence of Deglaciations in the Mid-Latitude European Climate. In Deglaciation: Processes, Causes and Consequences; Boone, M., Ed.; Nova Science Publishers: New York, NY, USA, 2017; pp. 107-140, ISBN 978-1-53612-501-6.

59. Martin-Garcia, G.M. Environmental Variations in the North Atlantic in Response to Quaternary Glaciations; Nova Science Publishers: New York, NY, USA, 2018; p. 139, ISBN 978-1-53613-367-7.

60. Martin-Garcia, G.M.; Alonso-Garcia, M.; Sierro, F.J.; Hodell, D.A.; Flores, J.A. Severe cooling episodes at the onset of deglaciations on the Southwestern Iberian margin from MIS 21 to 13 (IODP site U1385). Glob. Planet. Chang. 2015, 135, 159-169. [CrossRef]

61. Locarnini, R.A.; Mishonov, A.V.; Antonov, J.I.; Boyer, T.P.; Garcia, H.E.; Baranova, O.K.; Zweng, M.M.; Johnson, D.R. World Ocean Atlas 2009, Volume 1: Temperature; NOAA Atlas NESDIS 68; Levitus, S., Ed.; Government Printing Office: Washington, DC, USA, 2010; p. 184.

62. Martin-Garcia, G.M.; Sierro, F.J.; Hodell, D.A.; Flores, J.A. Climate oscillations on the SW Iberian Margin from 860 to $490 \mathrm{ka}$. In Proceedings of the VIII Conference MIA 2015, Málaga, Spain, 21-23 September 2015; pp. 429-432.

63. Kucera, M.; Weinelt, M.; Kiefer, T.; Pflaumann, U.; Hayes, A.; Weinelt, M.; Chen, M.; Mix, A.C.; Barrows, T.T.; Cortijo, E.; et al. Reconstruction of sea-surface temperatures from assemblages of planktonic foraminifera: Multi-technique approach based on geographically constrained calibration data sets and its application to glacial Atlantic and Pacific Oceans. Quat. Sci. Rev. 2005, 24, 951-998. [CrossRef]

64. Calvo, E.; Villanueva, J.; Grimalt, J.O.; Boelaert, A.; Labeyrie, L. New insights into the glacial latitudinal temperature gradients in the North Atlantic. Results from $\mathrm{Uk}_{37}^{\prime}$ sea surface temperatures and terrigenous inputs. Earth Planet. Sci. Lett. 2001, 188, 509-519. [CrossRef]

65. Naafs, B.D.A.; Stein, R.; Hefter, J.; Khélifi, N.; De Schepper, S.; Haug, G.H. Late Pliocene changes in the North Atlantic Current. Earth Planet. Sci. Lett. 2010, 298, 434-442. [CrossRef]

66. Voelker, A.H.L.; Rodrigues, T.; Billups, K.; Oppo, D.; McManus, J.; Stein, R.; Hefter, J.; Grimalt, J.O. Variations in mid-latitude North Atlantic surface water properties during the mid-Brunhes (MIS 9-14) and their implications for the thermohaline circulation. Clim. Past 2010, 6, 531-552. [CrossRef]

67. Eynaud, F.; De Abreu, L.; Voelker, A.; Schönfeld, J.; Salgueiro, E.; Turon, J.L.; Penaud, A.; Toucanne, S.; Naughton, F.; Goñi, M.F.; et al. Position of the Polar Front along the western Iberian Margin during key cold episodes of the last $45 \mathrm{ka}$. Geochem. Geophys. Geosyst. 2009, 10, Q07U05. [CrossRef]

68. Bard, E.; Rostek, F.; Turon, J.L.; Gendreau, S. Hydrological impact of Heinrich Events in the Subtropical Northeast Atlantic. Science 2000, 289, 1321-1324. [CrossRef] [PubMed]

69. Lebreiro, S.M.; Moreno, J.C.; McCave, I.N.; Weaver, P.P.E. Evidence for Heinrich layers off Portugal (Tore Seamount: $39^{\circ} \mathrm{N}, 12^{\circ} \mathrm{W}$ ). Mar. Geol. 1996, 131, 47-56. [CrossRef] 
70. Lebreiro, S.M.; Moreno, F.C.; Abrantes, F.; Pflaumann, U. Productivity and paleoceanographic implications on the Tore Seamount (Iberian Margin) during the last 225 kyr: Foraminiferal evidence. Paleoceanography 1997, 12, 718-727. [CrossRef]

71. Zahn, R.; Schönfeld, J.; Kudrass, H.R.; Park, M.H.; Erlenkeuser, H.; Grootes, P. Thermohaline instability in the North Atlantic during meltwater events: Stable isotope and ice-rafted detritus records from core SO75-26KL, Portuguese margin. Paleoceanography 1997, 12, 696-710. [CrossRef]

72. Cayre, O.; Lancelot, Y.; Vincent, E. Paleoceaanographic reconstructions from planktonic foraminifera ogg the Iberian Margin: Temperature, salinity and Heinrich events. Paleoceanography 1999, 14, 384-396. [CrossRef]

73. de Abreu, L.; Abrantes, F.; Shackleton, N.J.; Tzedakis, P.C.; McManus, J.F.; Oppo, D.W.; Hall, M.A. Ocean climate variability in the eastern North Atlantic during interglacial marine isotope stage 11: A partial analogue to the Holocene? Paleoceanography 2005, 20. [CrossRef]

74. Vautravers, M.J.; Shackleton, N.J. Centennial-scale surface hydrology off Portugal during marine isotope stage 3: Insights from planktonic foraminiferal fauna variability. Paleoceanography 2006, 21, PA3004. [CrossRef]

75. de Abreu, L.; Shackleton, N.J.; Schönfeld, J.; Hall, M.A.; Chapman, M. Millennial-scale oceanic climate variability off the western Iberian margin during the last two glacial periods. Mar. Geol. 2003, 196, 1-20. [CrossRef]

76. Martin-Garcia, G.M.; Sierro, F.J.; Flores, J.A.; Abrantes, F. Change in the North Atlantic circulation associated with the mid-Pleistocene transition. Clim. Past 2018, 14, 1639-1651. [CrossRef]

77. Martin-Garcia, G.M.; Sierro, F.J.; Flores, J.A. Reconstruction of North Atlantic circulation affecting the SW Iberian Margin during Glacial stages from 840 to $530 \mathrm{ka}$. In Proceedings of the VIII Conference MIA 2015, Málaga, Spain, 21-23 September 2015; pp. 237-240.

78. Alonso-Garcia, M.; Sierro, F.J.; Flores, J.A. Arctic front shifts in the subpolar north Atlantic during the Mid-Pleistocene (800-400 ka) and their implications for ocean circulation. PA3 2011, 311, 268-280. [CrossRef]

79. Hodell, D.; Lourens, L.; Crowhurst, S.; Konijnendijk, T.; Tjallingii, R.; Jiménez-Espejo, F.; Skinner, L.; Tzedakis, P.C.; Members, T.S.; Abrantes, F.; et al. A reference time scale for Site U1385 (Shackleton Site) on the SW Iberian Margin. Glob. Planet. Chang. 2015, 133, 49-64. [CrossRef]

80. Ruddiman, W.F.; Raymo, M.E.; Martinson, D.G.; Clement, B.M.; Backman, J. Sea surface temperature reconstruction of DSDP Site 94-607 in the North Atlantic. Paleoceanography 1989, 4, 353-412,. [CrossRef]

81. Sabine, C.L.; Feely, R.A.; Gruber, N.; Key, R.M.; Lee, K.; Bullister, J.L.; Wanninkhof, R.; Wong, C.S.; Wallace, D.W.R.; Tilbrook, B.; et al. The oceanic sink for anthropogenic $\mathrm{CO}_{2}$. Science 2004, 305, 367-371. [CrossRef] [PubMed]

82. Adkins, J. The role of deep ocean circulation in setting glacial climates. Paleoceanography 2013, 28, 539-561. [CrossRef]

83. Stocker, T.F. Past and future reorganisations in the climate system. Quat. Sci. Rev. 1999, 19, 301-319. [CrossRef]

84. Böhm, E.; Lippold, J.; Gutjahr, M.; Frank, M.; Blaser, P.; Antz, B.; Fohlmeister, J.; Frank, N.; Andersen, M.B.; Deininger, M. Strong and deep Atlantic meridional overturning circulation during the last glacial cycle. Nature 2014, 517, 73. [CrossRef]

85. Boyle, E.; Keigwin, L. North Atlantic thermohaline circulation during the past 20,000 years linked to high-latitude surface temperature. Nature 1987, 330, 35-40. [CrossRef]

86. Sarnthein, M.; Winn, K.; Jung, S.J.A.; Duplessy, J.C.; Labeyrie, L.; Erlenkeuser, H.; Ganssen, G. Changes in east Atlantic deepwater circulation over the last 30,000 years: Eight time slice reconstructions. Paleoceanography 1994, 9, 209-267. [CrossRef]

87. Lippold, J.; Gutjahr, M.; Blaser, P.; Christner, E.; de Carvalho Ferreira, M.L.; Mulitza, S.; Christl, M.; Wombacher, F.; Böhm, E.; Antz, B.; et al. Deep water provenance and dynamics of the (de)glacial Atlantic meridional overturning circulation. Earth Planet. Sci. Lett. 2016, 445, 68-78. [CrossRef]

88. Rühlemann, C.; Mulitza, S.; Müller, P.J.; Wefer, G.; Zahn, R. Warming of the tropical Atlantic Ocean and slowdown of thermohaline circulation during the last deglaciation. Nature 1999, 402, 511-514. [CrossRef]

89. Ruddiman, W.F.; Bowles, F.A. Late Quaternary deposition of ice-rafted sand in the sub-polar North Atlantic (lat $40^{\circ}$ to $65^{\circ}$ N). Geol. Soc. Am. Bull. 1977, 88, 1813-1827. [CrossRef]

90. Naafs, B.D.A.; Hefter, J.; Ferretti, P.; Stein, R.; Haug, G.H. Biomarker abundance in MIS 16 of IODP Site 306-U1313. Paleoceanography 2011. [CrossRef] 
91. George, S.E.; Saunders, M.A. North Atlantic Oscillation impact on tropical north Atlantic winter atmospheric variability. Geophy. Res. Lett. 2001, 28, 1015-1018. [CrossRef]

92. Trigo, R.M.; Pozo-Vázquez, D.; Osborn, T.J.; Castro-Díez, Y.; Gámiz-Fortis, S.; Esteban-Parra, M.J. North Atlantic oscillation influence on precipitation, river flow and water resources in the Iberian Peninsula. Int. J. Climatol. 2004, 24, 925-944. [CrossRef]

93. Hurrell, J.W. Influence of variations in extratropical wintertime teleconnections on northern hemisphere temperature. Geophys. Res. Lett. 1996, 23, 665-668. [CrossRef]

94. Tsimplis, M.N.; Josey, S.A. Forcing of the Mediterranean Sea by atmospheric oscillations over the North Atlantic. Geophys. Res. Lett. 2001, 28, 803-806. [CrossRef]

95. Hulme, M. A 1951-80 global land precipitation climatology for the evaluation of General Circulation Models. Clim. Dyn. 1992, 7, 57-72. [CrossRef]

96. Wanner, H.; Brönnimann, S.; Casty, C.; Gyalistras, D.; Luterbacher, J.; Schmutz, C.; Stephenson, D.B.; Xoplaki, E. North Atlantic oscillation-concepts and studies. Surv. Geophys. 2001, 22, 321-382. [CrossRef]

97. Cook, E.R.; D'Arrigo, R.D.; Briffa, K.R. The North Atlantic Oscillation and its expression in circum-Atlantic tree-ring chronologies from North America and Europe. Holocene 1998, 8, 9-17. [CrossRef]

98. Glueck, M.F.; Stockton, C.W. Reconstruction of the North Atlantic Oscillation. Int. J. Climatol. 2001, 21, 1453-1465. [CrossRef]

99. Barlow, L.H.; White, J.W.C.; Barry, R.G.; Rogers, J.C.; Grootes, P.M. The North Atlantic Oscillation signature in deuterium and deuterium excess signals in the Greenland ice sheet Project 2 ice core. Geophys. Res. Lett. 1993, 20, 2901-2904. [CrossRef]

100. White, J.W.C.; Gorodetzky, D.; Cook, E.R.; Barlow, L.K. Frequency analysis of an annually resolved, 700 year paleoclimate record from the GISP2 ice core. In Climate Variations and Forcing Mechanisms of the Last 2000 Years; Springer: New York, NY, USA, 1996; pp. 193-213.

101. Appenzeller, C.; Stocker, T.F.; Anklin, M. North Atlantic oscillation dynamics recorded in Greenland ice cores. Science 1998, 282, 446-449. [CrossRef] [PubMed]

102. Proctor, C.J.; Baker, J.; Barnes, W.L.; Gilmore, M.A. A thousand year speleothem proxy record of North Atlantic climate from Scotland. Clim. Dyn. 2000, 16, 815-820. [CrossRef]

103. Bard, E.; Antonioli, F.; Silenzi, S. Sea-level during the penultimate interglacial period based on a submerged stalagmite from Argentarola Cave (Italy). Earth Planet. Sci. Lett. 2002, 196, 135-146. [CrossRef]

104. Cullen, H.M.; D'Arrigo, R.; Cook, E.R.; Mann, M.E. Multiproxy reconstructions of the North Atlantic Oscillation. Paleoceanography 2000, 16, 27-39. [CrossRef]

105. Garcia, R.; Gimeno, L.; Hernandez, E.; Prieto, R.; Ribera, P. Reconstructing the North Atlantic atmospheric circulation in the 16th, 17th and 18th centuries from historical sources. Clim. Res. 2000, 14, 147-151. [CrossRef]

106. Luterbacher, J.; Xoplaki, E.; Dietrich, D.; Rickli, R.; Jacobeit, J.; Beck, C.; Gyalistras, D.; Schmutz, C.; Wanner, H. Reconstruction of sea level pressure fields over the eastern North Atlantic and Europe back to 1500. Clim. Dyn. 2001, 18, 545-561. [CrossRef]

107. Rodrigo, F.S.; Pozo-Vázquez, D.; Esteban-Parra, M.J.; Castro-Diez, Y. A reconstruction of the winter North Atlantic Oscillation Index back to AD 1501 using documentary data in southern Spain. J. Geophys. Res. 2001, 106, 14805-14818. [CrossRef]

108. Tremblay, L.B.; Mysak, L.A.; Dyke, A.S. Evidence from driftwood records for century- to-millennial scale variations of the high latitude atmospheric circulation during the Holocene. Geophys. Res. Lett. 1997, 24, 2027-2030. [CrossRef]

109. Tzedakis, P.C.; Hooghiemstra, H.; Palike, H. The last 1.35 million years at Tenaghi Philippon: Revised chronostratigraphy and long-term vegetation trends. Quat. Sci. Rev. 2006, 25, 3416-3430. [CrossRef]

110. Tzedakis, P.C.; Pälike, H.; Roucoux, K.H.; de Abreu, L. Atmospheric methane, southern European vegetation and low-mid latitude links on orbital and millennial timescales. Earth Planet. Sci. Lett. 2009, 277, 307-317. [CrossRef]

111. Margari, V.; Skinner, L.C.; Tzedakis, P.C.; Ganopolski, A.; Vautravers, M.; Shackleton, N.J. The nature of millennial-scale climate variability during the past two glacial periods. Nat. Geosci. 2010, 3, 127-131. [CrossRef] 
112. Margari, V.; Skinner, L.C.; Hodell, D.A.; Martrat, B.; Toucanne, S.; Grimalt, J.O.; Gibbard, P.L.; Lunkka, J.P.; Tzedakis, P.C. Land-ocean changes on orbital and millennial time scales and the penultimate glaciation. Geology 2014, 42, 183-186. [CrossRef]

113. Sánchez Goñi, M.F.; Llave, E.; Oliveira, D.; Naughton, F.; Desprat, S.; Ducassou, E.; Hodell, D.A.; Hernández-Molina, F.J. Climate changes in south western Iberia and Mediterranean Outflow variations during two contrasting cycles of the last 1 Myrs: MIS 31-MIS 30 and MIS 12-MIS 11. Glob. Planet. Chang. 2016, 136, 18-29. [CrossRef]

114. Sanchez Goñi, M.F.; Desprat, S.; Daniau, A.; Cacho, I.; Turon, J.; Guiot, J.; Sierro Sánchez, F.J.; Peypouquet, J.P.; Grimalt, J.O.; Shackleton, N.J.; et al. CLAM age model and pollen profile of sediment core MD95-2043. PANGAEA 2017. [CrossRef]

115. Barnston, A.G.; Livezey, R.E. Classification, seasonality and persistence of low frequency atmospheric circulation patterns. Mon. Wea. Rev. 1987, 115, 1083-1126. [CrossRef]

116. Peng, S.; Mysak, L.A. A teleconnection study of interannual sea surface temperature fluctuations in the North Atlantic and precipitation and runoff over western Siberia. J. Clim. 1993, 6, 876-885. [CrossRef]

117. Peng, S.; Mysak, L.A.; Ritchie, H.; Derome, J.; Dugas, B. The differences between early and midwinter atmospheric responses to sea surface temperature anomalies in the northwest Atlantic. J. Clim. 1995, 8, 137-157. [CrossRef]

118. Czaja, A.; Frankignoul, C. Influence of the North Atlantic SST on the atmospheric circulation. Geophys. Res. Lett. 1999, 26, 2969-2972. [CrossRef]

119. Higuchi, K.; Huang, J.; Shabbar, A. A wavelet characterization of the North Atlantic oscillation variation and its relationship to the North Atlantic sea surface temperature. Int. J. Climatol. 1999, 19, 1119-1129. [CrossRef]

120. Rodwell, M.J.; Rowell, D.P.; Folland, C.K. Oceanic forcing of the wintertime North Atlantic Oscillation and European climate. Nature 1999, 398, 320-323. [CrossRef]

121. Mehta, V.M.; Suarez, M.J.; Manganello, J.V.; Delworth, T.L. Oceanic influence on the North Atlantic Oscillation and associated Northern Hemisphere climate variations: 1959-1993. Geophy. Res. Lett. 2000, 27, 121-124. [CrossRef]

122. Robertson, A.W.; Mechoso, C.R.; Young-Joon, K. The influence of Atlantic sea surface temperature anomalies on the North Atlantic Oscillation. J. Clim. 2000, 13, 122-138. [CrossRef]

123. Enfield, D.B.; Mestas-Nunez, A.M.; Trimble, P.J. The Atlantic Multidecadal Oscillation and its relationship to rainfall and river flows in the Continental U.S. Geophys. Res. Lett. 2001, 28, 2077-2080. [CrossRef]

124. Stephenson, D.B.; Pavan, V.; Bojariu, R. Is the North Atlantic Oscillation a random walk? Int. J. Climatol. 2000, 20, 1-18. [CrossRef]

125. Nobre, P.; Shukla, J. Variations of sea surface temperature, wind stress, and rainfall over the tropical Atlantic and South America. J. Clim. 1996, 9, 2464-2479. [CrossRef]

126. Sánchez Goñi, M.F.; Landais, A.; Fletcher, W.J.; Naughton, F.; Desprat, S.; Duprat, J. Contrasting impacts of Dansgaard-Oeschger events over a western European latitudinal transect modulated by orbital parameters. Quat. Sci. Rev. 2008, 27, 1136-1151. [CrossRef]

127. Wainer, K.; Genty, D.; Blamart, D.; Bar-Matthews, M.; Quinif, Y.; Plagnes, V. Millennial climatic instability during penultimate glacial period recorded on a south-western France speleothem. Palaeog. Palaeocl. Palaeoec. 2013, 376, 122-131. [CrossRef]

128. Roucoux, K.H.; de Abreu, L.; Shackleton, N.J.; Tzedakis, P.C. The response of NW Iberian vegetation to North Atlantic climate oscillations during the last 65 kyr. Quat. Sci. Rev. 2005, 24, 1637-1653. [CrossRef]

129. Combourieu, N.; Bordon, A.; Peyron, O.; Kageyama, M.; Cazet, J.P. Mediterranean climate during the short-time events of the last Deglaciation and the Holocene: Seasonality and gradient according to vegetation changes. Geoph. Res. Abs. 2007, 9, 07575.

130. Sánchez Goñi, M.F.; Bard, E.; Landais, A.; Rossignol, L.; d’Errico, F. Air-sea temperature decoupling in western Europe during the last interglacial-glacial transition. Nat. Geosci. 2013. [CrossRef]

131. Stocker, T.F.; Mysak, L.A. Climatic Fluctuations on the Century Timescale; A Review of High-Resolution Proxy-Data; McGill University: Montreal, QC, Canada, 1989; pp. 89-113.

132. Rahmstorf, S. Ocean circulation and climate during the past 120,000 years. Nature 2002, 419, $207-214$. [CrossRef] [PubMed]

133. Timmermann, A.M.; Latif, M.; Voss, R.; Grotzner, A. Northern hemispheric interdecadal variability: A coupled air-sea mode. J. Clim. 1998, 11, 1906-1931. [CrossRef] 
134. Delworth, T.L.; Manabe, S.; Stouffer, R.J. Interdecadal variations of the thermohaline circulation in a coupled ocean-atmosphere model. J. Clim. 1993, 6, 1993-2011. [CrossRef]

135. Taylor, A.H.; Stephens, J.A. The North Atlantic Oscillation and the latitude of the Gulf Stream. Tellus 1998, 50A, 134-142. [CrossRef]

136. Frankignoul, C.; de Coëtlogon, G.; Joyce, T.M. Gulf Stream variability and ocean-atmosphere interactions. J. Phys. Ocean. 2001, 31, 3516-3529. [CrossRef]

137. Buizert, C.; Adrian, B.; Ahn, J.; Albert, M.; Alley, R.B.; Baggenstos, D.; Bauska, T.K.; Bay, R.C.; Bencivengo, B.B.; Bentley, C.R.; Brook, E.J. Precise interpolar phasing of abrupt climate change during the last ice age. Nature 2015, 520, 661-665. [CrossRef]

138. Henry, L.G.; McManus, J.F.; Curry, W.B.; Roberts, N.L.; Piotrowski, A.M.; Keigwin, L.D. North Atlantic ocean circulation and abrupt climate change during the last glaciation. Science 2016, 353, 470-474. [CrossRef]

139. Lynch-Stieglitz, J. The Atlantic Meridional Overturning Circulation and Abrupt Climate Change. Annu. Rev. Mar. Sci. 2017, 9, 83-104. [CrossRef]

140. Moreno, A.; Cacho, I.; Canals, M.; Grimalt, J.O.; Sánchez-Goñi, M.F.; Shackleton, N.; Sierro, F.J. Links between marine and atmospheric processes oscillating on a millennial time-scale. A multi-proxy study of the last 50,000 yrs from the Alboran Sea (Western Mediterranean Sea). Quat. Sci. Rev. 2005, 24, 1623-1636. [CrossRef]

141. Yi, D.; Mysak, L.A.; Venegas, S.A. Decadal-to-interdecadal fluctuations of Arctic sea-ice cover and the atmospheric circulation during 1954-1994. Atmos. Ocean 1999, 37, 389-415. [CrossRef]

142. Koslowski, G.; Loewe, P. The western Baltic sea ice season in terms of a mass-related severity index: 1879-1992, Part I: Temporal variability and association with the North Atlantic Oscillation. Tellus 1994, 46A, 66-74. [CrossRef]

143. Koslowski, G.; Glaser, R. Variations in reconstructed ice winter severity in the Western Baltic from 1501 to 1995, and their implications for the North Atlantic Oscillation. Clim. Chan. 1999, 41, 175-191. [CrossRef]

144. Vinje, T. Anomalies and trends of sea-ice extent and atmospheric circulation in the Nordic Seas during the period 1864-1998. J. Clim. 2001, 14, 255-267. [CrossRef]

145. Tzedakis, P.C. Towards an understanding of the response of southern European vegetation to orbital and suborbital climate variability. Quat. Sci. Rev. 2005, 24, 1585-1599. [CrossRef]

146. Parrenin, F.; Paillard, D. Amplitude and phase of glacial cycles from a conceptual model. Earth Planet. Sci. Lett. 2003, 214, 243-250. [CrossRef]

147. Fletcher, W.J.; Goni, M.F.; Allen, J.R.; Cheddadi, R.; Combourieu-Nebout, N.; Huntley, B.; Lawson, I.; Londeix, L.; Magri, D.; Margari, V.; et al. Millennial-scale variability during the last glacial in vegetation records from Europe. Quat. Sci. Rev. 2010, 29, 2839-2864. [CrossRef]

148. Ayalon, A.; Bar-Matthews, M.; Kaufman, A. Climatic conditions during marine oxigen isotope stage 6 in the Eastern Mediterranean region from the isotopic composition of speleothems of Soreq Cave, Israel. Geology 2002, 30, 303-306. [CrossRef]

(C) 2019 by the author. Licensee MDPI, Basel, Switzerland. This article is an open access article distributed under the terms and conditions of the Creative Commons Attribution (CC BY) license (http:/ / creativecommons.org/licenses/by/4.0/). 